Article

\title{
Formaldehyde Total Oxidation on Manganese-Doped Hydroxyapatite: The Effect of Mn Content
}

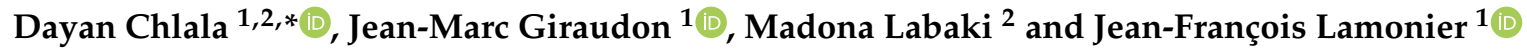 \\ 1 Unité de Catalyse et Chimie du Solide (UMR 8181-UCCS), University of Lille, CNRS, Centrale Lille, \\ Artois University, F-59000 Lille, France; jean-marc.giraudon@univ-lille.fr (J.-M.G.); \\ jean-francois.lamonier@univ-lille.fr (J.-F.L.) \\ 2 Laboratory of Physical Chemistry of Materials (LCPM)/PR2N, Faculty of Sciences, Lebanese University, \\ Fanar, Jdeidet El Metn BP 90656, Lebanon; mlabaki@ul.edu.lb \\ * Correspondence: dayan.chlala@ul.edu.lb
}

Received: 29 October 2020; Accepted: 25 November 2020; Published: 4 December 2020

check for updates

\begin{abstract}
An aqueous impregnation method using manganese (II) nitrate precursor, followed by calcination at $400{ }^{\circ} \mathrm{C}$, was carried out for the preparation of manganese doped hydroxyapatite catalysts (MnxHap; x = Mn wt.\%: 2.5, 5.0, 10, 20, and 30 based on $\mathrm{MnO}_{2}$ ). Methods of characterization including inductively coupled plasma spectroscopy (ICP), $\mathrm{N}_{2}$ physisorption, X-ray Diffraction (XRD), Fourier-Transform Transmission Infrared (FT-IR), Raman, and Thermal gravimetric analysis (TGA/MS) analysis were used for the identification of Mn species and its surrounding environment. Raman spectroscopy indicated the presence of the $\varepsilon-\mathrm{MnO}_{2}$ phase for $\mathrm{Mn} 20 \mathrm{Hap}$ and $\mathrm{Mn} 30 \mathrm{Hap}$ in agreement with the XRD results and the presence of $\beta-\mathrm{MnOOH}$ species for Mn5Hap and Mn10Hap. The formaldehyde total oxidation was investigated on these catalysts and it was shown that Mn5Hap was the most active catalyst, achieving a normalized rate of formaldehyde ( $\mathrm{HCHO}$ ) conversion into $\mathrm{CO}_{2}$ per mole of $\mathrm{Mn}$ of $0.042 \mathrm{~h}^{-1}$ at a temperature of $145^{\circ} \mathrm{C}$. The well dispersed oxidized manganese species on Hap with a medium Mn AOS (average oxidation state) were mainly responsible for this performance. Since HCHO was retained on the surface of all catalysts during the catalytic test, the combined Diffuse Reflectance Infrared Fourier Transform spectroscopy (DRIFT) experiment at room temperature and thermodesorption (TD)-FTIR identified formate species as their oxidation consumed surface $\mathrm{OH}$ groups. A stability test and moisture effect study showed that the presence of water vapor has a beneficial effect on the performances of the catalyst.
\end{abstract}

Keywords: hydroxyapatite; formaldehyde; manganese; total oxidation

\section{Introduction}

Formaldehyde that is mainly released from coating and adhesive agents for building materials is of great concern due to the fact that formaldehyde $(\mathrm{HCHO})$ is an irritant and carcinogenic volatile organic compound (VOC). This VOC has very harmful effects on the human body, leading to the well-known sick house syndrome. The removal of formaldehyde from existing buildings is of major concern due to stringent legislation surrounding its removal. Among other methods, catalytic oxidation can be one possible attractive technology for the selective elimination of HCHO [1,2]. Total oxidation of $\mathrm{HCHO}$ into $\mathrm{CO}_{2}$ and $\mathrm{H}_{2} \mathrm{O}$ has been reported to take place in the presence of supported noble metal catalysts that are operating at low temperatures $\left(<150^{\circ} \mathrm{C}\right)[3,4]$ and even at room temperature in some cases [5]. However, research investigating less costly active options that do not involve noble metals is of considerable interest from an economic point of view. In this context, both supported and unsupported transition metal oxides have been used for the selective eliminate of $\mathrm{HCHO}$ due to their acid-base and redox properties [6]. Among them, $\mathrm{Mn}_{\mathrm{x}} \mathrm{O}_{\mathrm{y}}$ have been studied by several groups due to 
their low volatility and low toxicity. Manganese oxides adopt a wide range of stoichiometry and crystal phases and show excellent efficiency towards achieving HCHO elimination at low temperatures [7]. The ability to switch easily between different oxidation states and the possibility of accommodating defect formations have been put forward to explain such good catalytic performances [8].

In terms of $\mathrm{Mn}$ valence, $\mathrm{MnO}_{2}$ oxide has been claimed to show a higher activity than that of the mixed $\mathrm{Mn}^{3+/ 2+}$ valence $\mathrm{Mn}_{3} \mathrm{O}_{4}$ oxide [9]. This was consistent with the works of Quiroz Torres et al. [10] showing an increase of the intrinsic $\mathrm{HCHO}$ oxidation rate into $\mathrm{CO}_{2}$ by a factor of 1.4 over an acid-treated catalyst containing $\mathrm{Mn}_{2} \mathrm{O}_{3} / \mathrm{Mn}_{3} \mathrm{O}_{4} / \mathrm{Mn}_{2} \mathrm{O}_{5}$ phases. This reactivity improvement was mainly related to the promotion of redox properties due to the presence of manganese species at higher oxidation state taking advantage of the disproportionation of $\mathrm{Mn}(+\mathrm{III})$. Based on these works highlighting the potential applications of $\mathrm{MnO}_{2}$ in $\mathrm{HCHO}$ elimination, different strategies were adopted to enhance catalytic activities of such materials. Recently a Top-Down approach [11] was proposed for the preparation of high specific surface area $\alpha-\mathrm{MnO}_{2}$ (cryptomelane). An "Activated Reactive Synthesis" consisting of a High Energy Ball Mill (HEBM) followed by a Low Energy Ball Mill (LEBM) was applied to a commercial $\alpha-\mathrm{MnO}_{2}$ oxide. The efficiency of this approach was validated by an 8 -fold increase of the specific surface area in the optimized conditions of preparation. Although $100 \% \mathrm{HCHO}$ can be achieved at $175^{\circ} \mathrm{C}$ on the best catalyst, contamination by iron at present precludes activity enhancement.

Another possible way to achieve activity enhancement was to investigate the effect of $\mathrm{MnO}_{2}$ structures. In this context, the square tunnel dimension of related one-dimensional tunnel $\mathrm{MnO}_{2}$ oxides was recognized to play a key role in $\mathrm{HCHO}$ oxidation. It turned out that cryptomelane having a $2 \times 2$ square tunnel of $0.46 \times 0.46 \mathrm{~nm}^{2}$ showed the best performances, achieving $100 \% \mathrm{CO}_{2}$ at $140{ }^{\circ} \mathrm{C}$ (HCHO: 400 ppmv; Volume Hourly Space Velocity (VHSV) $=18,000 \mathrm{~mL} \mathrm{~g}^{-1} \mathrm{~h}^{-1}$ ) [12]. The effect of the morphology upon catalytic $\mathrm{HCHO}$ total oxidation was subsequently studied on this material by Tian et al. [12]. The best reactivity toward HCHO removal observed on nanoparticles compared to nanorods was explained by a better accessibility of the channel [13]. In that regard, formation of new flower-like cryptomelane particles were reported to exhibit high activity due to their hierarchical structure, large surface area, and large pore size allowing a better diffusion of the reactants [14]. In a similar way, the flake-type morphology of birnessite material (exhibiting a two-dimensional layer) showed a $100 \%$ formaldehyde conversion at $100{ }^{\circ} \mathrm{C}$ [15].

In order to increase the dispersion of the active $\mathrm{MnO}_{x}$ phase, the synthesis and physicochemical characterization of mesoporous silica supported manganese oxide have been reported by Averlant et al. [16]. Different impregnation routes have been carried out. As a result, the conventional aqueous impregnation followed by a calcination at $200{ }^{\circ} \mathrm{C}$ was found to obtain the best catalytic performances $\left(100 \% \mathrm{HCHO}\right.$ achieved at $\left.130{ }^{\circ} \mathrm{C}, \mathrm{Mn}(\mathrm{wt} \%)=20\right)$. Manganese mainly dispersed as $\beta-\mathrm{MnO}_{2}$ on the external surface of $\mathrm{SiO}_{2}$ accounts for such good performances.

As an attractive alternative, hydroxyapatite (Hap) of ideal formula $\mathrm{Ca}_{10}\left(\mathrm{PO}_{4}\right)_{6}(\mathrm{OH})_{2}$, in foam, has been previously designed as an inexpensive material with active sites for promoting lowtemperature catalytic combustion of formaldehyde in moist air [17]. The authors reported the beneficial role of hydroxyl groups bonded within the channel $\mathrm{Ca}^{2+}$ to be responsible for adsorption/activation of $\mathrm{HCHO}$. Although the $\mathrm{HCHO}$ conversion rate $(\approx 1400$ ppmv in moist air, relative humidity $(\mathrm{RH}) \approx$ $8.0 \%$ ) into $\mathrm{CO}_{2}$ amounts to $45 \%$ at room temperature, $100 \% \mathrm{HCHO}$ conversion can only be achieved at a temperature of $280^{\circ} \mathrm{C}$.

For a given metal, the dispersion and nature of metal species on a given support depend, among other things, on the nature of the metal precursor, method of preparation (including ion exchange, co-precipitation, impregnation), and temperature of calcination. However, when considering hydroxyapatite, the flexibility in terms of $\mathrm{Ca}^{2+}, \mathrm{PO}_{4}{ }^{3-}$, and $\mathrm{OH}^{-}$substitution has to also be considered. Some pioneer works have been carried out by our group in order to highlight the nature and location of manganese species when using a conventional precipitation route on hydroxyapatite followed by calcination at $400{ }^{\circ} \mathrm{C}$. The effect of the counter-anion of the manganese (II) salt was first investigated to be correlated with the performances of the final catalyst in toluene total oxidation [18]. It has been 
shown that, after calcination at $400{ }^{\circ} \mathrm{C}$, the nitrate $\mathrm{Mn}$ (II) precursor allows for getting well dispersed Mn oxidized species on a $\mathrm{Ca}^{2+}$ enriched surface, leading to a good toluene conversion $(\mathrm{Mn}(\mathrm{wt} \%)=10$; Temperature at which $50 \%$ toluene has been converted $\left(T_{50}\right)=203{ }^{\circ} \mathrm{C}$; VHSV $\left.=500 \mathrm{~mL} \mathrm{~g}^{-1} \mathrm{~h}^{-1}\right)$. In a second paper, the effect of Mn loading over hydroxyapatite on Mn speciation was investigated to be correlated to the catalytic performances in toluene oxidation [19].

In this study, aqueous precipitation of manganese (II) nitrate, using different Mn content, on hydroxyapatite followed by calcination at $400{ }^{\circ} \mathrm{C}$ have been used for the preparation of MnxHap ( $\mathrm{x}=\mathrm{Mn}$ wt $\%: 2.5,5,10,20$, and 30). Different characterizations were used to identify the nature of manganese species to be correlated with the catalytic performances in $\mathrm{HCHO}$ total oxidation.

\section{Results and Discussion}

\subsection{Textural and Structural Properties}

The chemical composition values and textural properties of the calcined materials are shown in Table 1. The experimental Mn contents are of the same order relative to the theoretical ones with the margin of error except the Mn30Hap, which has a lower value than expected.

Table 1. Chemical composition (CC) and textural properties of the calcined solids.

\begin{tabular}{|c|c|c|c|c|}
\hline \multirow{2}{*}{ Solids } & $\mathrm{CC}$ & $\mathrm{dc}^{\mathrm{a}}$ & $\mathrm{SSA}^{\mathrm{c}}$ & $V p^{d}$ \\
\hline & $\operatorname{Mn}(w t \%)$ & $(\mathrm{nm})$ & $\left(m^{2} g^{-1}\right)$ & $\left(\mathrm{cm}^{3} \mathrm{~g}^{-1}\right)$ \\
\hline Hap & - & & 94 & 0.59 \\
\hline Mn2.5Нар & 2.9 & - & 84 & 0.44 \\
\hline Mn5Hap & 5.8 & - & 84 & 0.44 \\
\hline Mn10Hap & 11.0 & - & 76 & 0.38 \\
\hline Mn20Hap & 20.1 & 9 & 70 & 0.39 \\
\hline Mn30Hap & 27.5 & $9\left(36^{b}\right)$ & 32 & 0.18 \\
\hline
\end{tabular}

Results of $\mathrm{N}_{2}$ physisorption are presented in Figure $\mathrm{S} 1$ and the textural properties are gathered in Table 1. Specific surface area (SSA) and Pore volume (Vp) of Hap support were $94 \mathrm{~m}^{2} \mathrm{~g}^{-1}$ and $0.59 \mathrm{~cm}^{3} \mathrm{~g}^{-1}$, respectively. After Mn addition, these values decreased by about $10-24 \%$ up to $x=20$, whereas a detrimental decrease $(66 \%)$ was observed for a higher Mn loading. The nitrogen adsorption-desorption isotherms for Hap and Hap-supported Mn samples display the characteristic hysteresis loop of a Type IV(a) isotherm (IUPAC) lying in the P/P0 range of 0.7-0.99 exhibiting an mesoporous character, as shown in Figure S1.

The X-ray diffraction patterns for MnxHap are gathered in Figure 1 and the different peaks belonging to the structures contributing to the refined X-ray diffraction pattern using the Rietveld method are displayed in Figure S2a-c. The X-ray diffraction patterns of MnxHap $(x \leq 10)$ appear to be very similar to that of monoclinic Hap (JCPDS file: 01-076-0694) up to Mn $10 \mathrm{wt} \%$ in accordance with Mn oxidized species below the detection limit and/or well dispersed and/or amorphous $\mathrm{MnO}_{\mathrm{x}}$ species (Figure 1). The X-ray diffraction pattern of Mn20Hap shows a new peak located at about $37.2^{\circ}$ and overlapping peaks in $2 \theta$ ranges: $42.5-43.5$ and $55-58^{\circ}$. Rietveld analysis indicates that the $X$-ray pattern given in Figure $\mathrm{S} 2 \mathrm{~b}$ can be adequately described using hexagonal $\varepsilon-\mathrm{MnO}_{2}$ (Akhtenskite; JCPDS file: 01-089-5171) along Hap. The $\varepsilon-\mathrm{MnO}_{2}$ structure can be described as a NiAs unit cell where the $\mathrm{Mn}(\mathrm{IV})$ cations are randomly distributed in half of the octahedral positions of the hexagonal close-packed (hcp) oxygen sub-lattice [20]. This structure is recognized to be similar to that of $\gamma-\mathrm{MnO}_{2}$ but exhibiting more structural faults and micro-twinning than $\gamma-\mathrm{MnO}_{2}$ [21]. The X-ray pattern of $\mathrm{Mn} 30 \mathrm{Hap}$ is consistent with the presence of $\varepsilon-\mathrm{MnO}_{2}$ and rhombohedral calcite $\mathrm{CaCO}_{3}$ (JCPDS file: 01-085-1108) having mean crystallite sizes of 9 and $36 \mathrm{~nm}$, respectively, without excluding the occurrence of $\alpha-\mathrm{Mn}_{2} \mathrm{O}_{3}$ (JCPDS file: 01-089-2809) in accordance with a relative increase in peak intensity at $32.9^{\circ}$, which has not been taken in account in the simulation. 


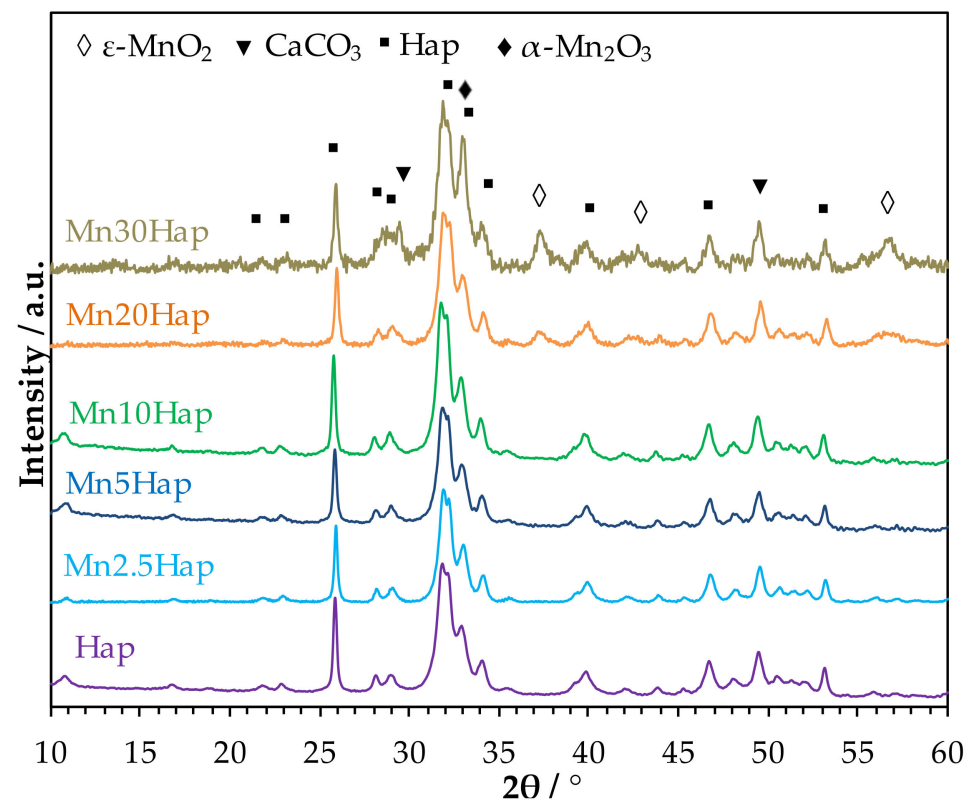

Figure 1. X-ray diffraction pattern of pure Hap and MnxHap samples.

Figure 2 displays the superposition of the Fourier-Transform Transmission Infrared (FT-IR) spectra of Hap support and MnxHap samples. The broad vibrational band in the $3500-3700 \mathrm{~cm}^{-1}$ range has been ascribed to the presence of adsorbed and constitutive water molecules, as shown in Figure 2a. The small band observed at $3571 \mathrm{~cm}^{-1}$ for the Hap support corresponds to structural hydroxyl groups [22], while the bands at 1030 and $1100 \mathrm{~cm}^{-1}$ are assigned to fundamental vibrational modes of $\mathrm{PO}_{4}{ }^{3-}$ groups in Hap [23,24]. The broad multicomponent contribution observed between 1550-1350 $\mathrm{cm}^{-1}$ is assignable to the presence of carbonate groups, which have been mainly incorporated during the synthesis of the material. Their assignments are still controversial in the literature, probably due to the fact that the conditions of collection of the spectra greatly impact the shape of the spectra, as observed by Diallo-Garcia et al. [25], and mainly affect the method for $\mathrm{CO}_{3}{ }^{2-}$ band assignment due to strong band overlapping [26]. FT-IR spectrum of the hydroxyapatite sample in the $1600-1350 \mathrm{~cm}^{-1}$ range shown in Figure $2 \mathrm{~b}$ allows for observing bands at $1545 \mathrm{~cm}^{-1}, 1500 \mathrm{~cm}^{-1}, 1452 \mathrm{~cm}^{-1}$, and $1415 \mathrm{~cm}^{-1}$. Based on literature data, the apparent maximum at $1452 \mathrm{~cm}^{-1}$ can be viewed as the overlapping of 2 bands at about 1456 and $1445 \mathrm{~cm}^{-1}$ [26]. The bands positioned at $1500 \mathrm{~cm}^{-1}, 1445 \mathrm{~cm}^{-1}$ and $1415 \mathrm{~cm}^{-1}$ have been previously assigned by Cheng et al. to $\mathrm{CO}_{3}{ }^{2-}$ substituting $\mathrm{OH}^{-}$groups, which thus lead to the formation of A-type apatites [26]. The remaining bands at $1456 \mathrm{~cm}^{-1}$ and $1545 \mathrm{~cm}^{-1}$ have been attributed by the same team to $\mathrm{CO}_{3}{ }^{2-}$ substituting $\mathrm{PO}_{4}{ }^{3-}$ groups, which thus lead to the formation of B-type apatites. The broad vibrational band in the 1350-1550 $\mathrm{cm}^{-1}$ range for the Mn30Hap catalyst Figure $2 \mathrm{~b}$ can be consistent with the overlapping of these previous bands with those $\mathrm{CO}_{3}{ }^{2-}$ bands that originated from $\mathrm{CaCO}_{3}$, as confirmed by XRD. The FT-IR spectra thus confirmed the combined A and B-type substitution by $\mathrm{CO}_{3}{ }^{2-}$ groups for all MnxHap samples. Neither band was significantly affected by the introduction of Mn. However, the detection of a sharp band at $1385 \mathrm{~cm}^{-1}$ whose intensity increases with $\mathrm{Mn}$ loading, attested to the presence of residual $\mathrm{NO}_{3}{ }^{-}$species. This shows that despite a temperature of calcination of $400{ }^{\circ} \mathrm{C}$ for $4 \mathrm{~h}$, a significant amount of $\mathrm{NO}_{3}{ }^{-}$still remained on the catalyst. It is noteworthy that FT-IR analysis precludes getting valuable information of $\mathrm{MnO}_{\mathrm{x}}$ phase in the $500-600 \mathrm{~cm}^{-1}$ region (not shown here), as expected bands were obscured by some bands of hydroxyapatite. 

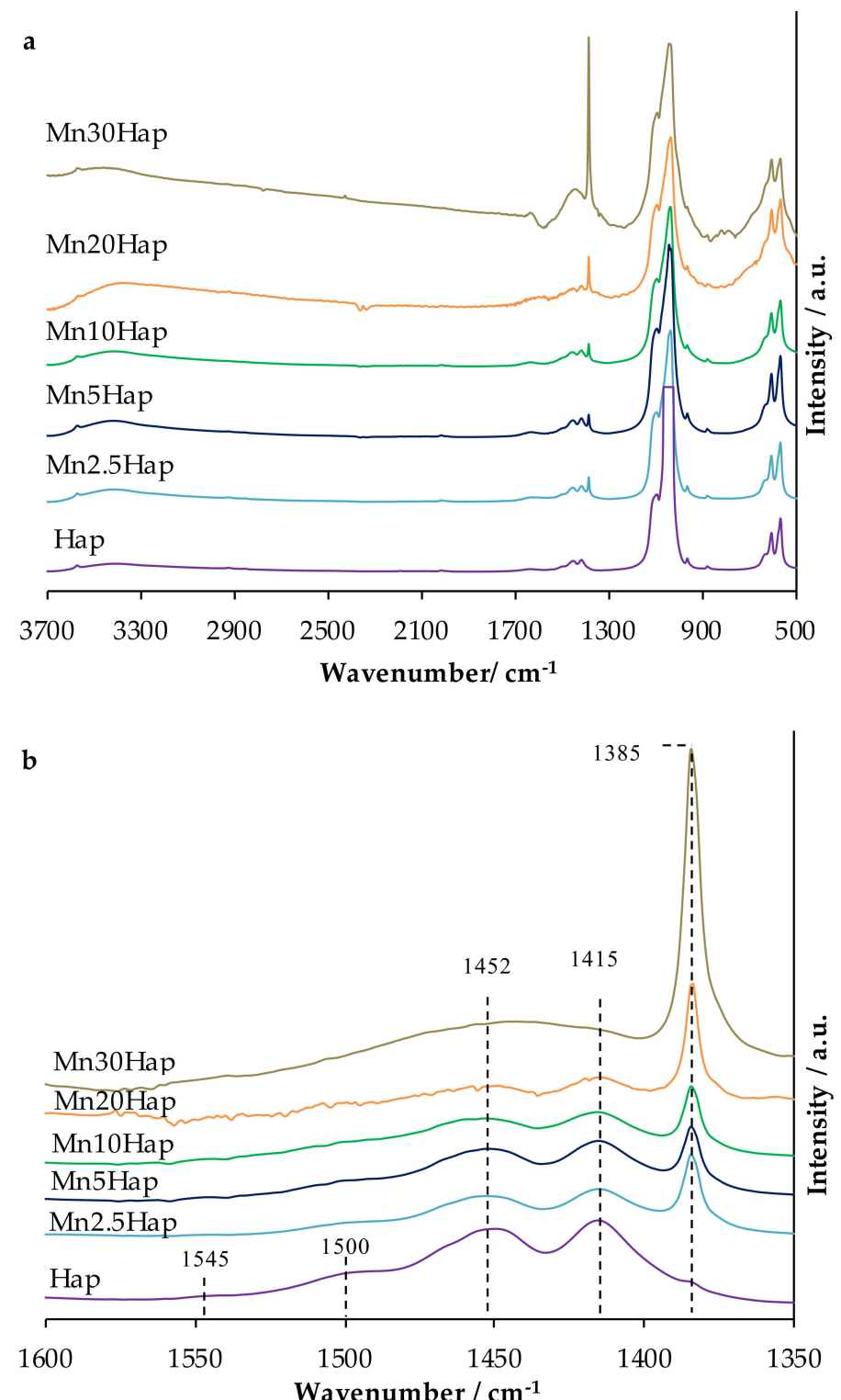

Figure 2. Fourier-Transform Transmission Infrared (FT-IR) spectra of Hap and Hap supported Mn catalysts with different loadings in the (a) $500-3700 \mathrm{~cm}^{-1}$ and (b) $1350-1600 \mathrm{~cm}^{-1}$ window.

Figure 3a-e shows the Raman scattering spectra of MnxHap catalysts. The characteristic peaks of Hap can be observed in Figure 3a [27]. It is noteworthy that there was no significant shift of the band located at $960 \mathrm{~cm}^{-1}\left(v_{1}\right.$ mode of $\left.\mathrm{PO}_{4}{ }^{3-}\right)$. The typical Raman spectra (RS) of different grains of Mn2.5Hap catalyst are presented in Figure 3a. Some only grains reveal the characteristic RS features of the support, while the RS spectra of few grains additionally exhibit a broad envelope due to overlapping of Raman scattering contributions at $580(\mathrm{~s}), 640(\mathrm{~s}) \mathrm{cm}^{-1}$ as well as weak RS contributions located at $435(w)$, $510(w)$, and $710(w) \mathrm{cm}^{-1}$. All these RS features are likely related to Mn oxidized species located in an octahedral environment as impurities [28]. As the XPS Mn average oxidation state (AOS) has been found to have a value close to $+2.0, \mathrm{Ca}^{2+}$ ions have been supposed to be substituted for $\mathrm{Mn}^{2+}$ ions in the Hap lattice, as reported previously [19,29-31]. However, the exact substitution of $\mathrm{Ca}^{2+}$ for $\mathrm{Mn}^{2+}$ in site 1 (Ca1: columnar $\mathrm{Ca}$ atoms parallel to $\mathrm{c}$ axis) or in site 2 (Ca2: triangular $\mathrm{Ca}$ sites along the $\mathrm{C}$ axis of Hap) remains still challenging. Pon-On et al. [32] reported that $\mathrm{Mn}^{2+}$ ions substituted for the nine-fold coordinated $\mathrm{Ca}^{2+}$ ions based on Electron Spin Resonance (ESR) analysis of data. Conversely Lala et al. [33] postulated that the Ca2 vacancy site would be more favorable for Mn substitution due to XRD data analysis but using another synthesis procedure. However, complementary experiments have 
to be implemented to assess such an assumption. The Mn related RS features are mainly preserved for Mn5Hap (see Mn5Hap(A) in Figure 3b). However, bands at 495, 553, and $635 \mathrm{~cm}^{-1}$ have been observed for Mn5Hap(B) and peaks at 504, 556 and $636 \mathrm{~cm}^{-1}$ for Mn10Hap(B) Figure 3b,c. These three bands can be attributed to stretching vibrations in octahedral $\mathrm{MnO}_{6}$ [28]. Although these Raman spectra are consistent with those of layered birnessite-type manganese oxide, the X-ray Photoelectron Spectroscopy (XPS) Mn AOS of +3.0 and +3.1 for Mn5Hap and Mn10Hap, respectively, obtained from our previous work [19], differ from that of birnessite $(+3.6$ to +3.8) [34]. In accordance with the works of Wang et al. [35], these bands have been ascribed to Feitknechtite $\beta-\mathrm{MnOOH}$, which has hexagonal layered structure. $\beta-\mathrm{MnOOH}$ has been herein considered as the predominant $\mathrm{MnOx}$ component of $\mathrm{Mn} 5 \mathrm{Hap}$ and $\mathrm{Mn} 10 \mathrm{Hap}$. One possible reason for the existence of $\beta-\mathrm{MnOOH}$ can be the reduction of some expected $\mathrm{MnO}_{2}$ phase to be reduced back into $\mathrm{MnOOH}$ by $\mathrm{Mn}^{2+}$ dissolved in the hydroxyapatite. The Raman Mn30Hap(A) spectrum displays lines at 646, 599, 532 and $470 \mathrm{~cm}^{-1}$ (see Figure 3e) in close agreement with those reported for $\varepsilon-\mathrm{MnO}_{2}$ and corroborate our results of XRD data analysis [36]. The same observation was found for Mn20Hap (Figure 3d). Other grains (Mn30Hap(B)) reveal a broad envelope between $400-800 \mathrm{~cm}^{-1}$ due to overlapping peaks of $\varepsilon-\mathrm{MnO}_{2}$, which is probably in line with smaller particle sizes. Also, the Raman spectrum $\mathrm{Mn} 30 \mathrm{Hap}(\mathrm{C})$ of some grains displays additional intense peaks at 326, 775, and $807 \mathrm{~cm}^{-1}$ ascribed respectively to $v_{2}, v_{3}$, and $v_{1} \mathrm{MnO}_{4}{ }^{3-}$ vibrational modes [37]. This indicates that some $\mathrm{Mn}(\mathrm{V})$ replace $\mathrm{P}(\mathrm{V})$ in the phosphate lattice, as already noticed in the literature [37]. However, it is expected that this $\mathrm{Mn}(\mathrm{V})$ amount is low due to pre-resonance effects [37]. Additionally, a line at $1050 \mathrm{~cm}^{-1}$ was observed for all samples, which has been ascribed to the $v_{4}$ mode of remaining $\mathrm{NO}_{3}{ }^{-}[38]$.
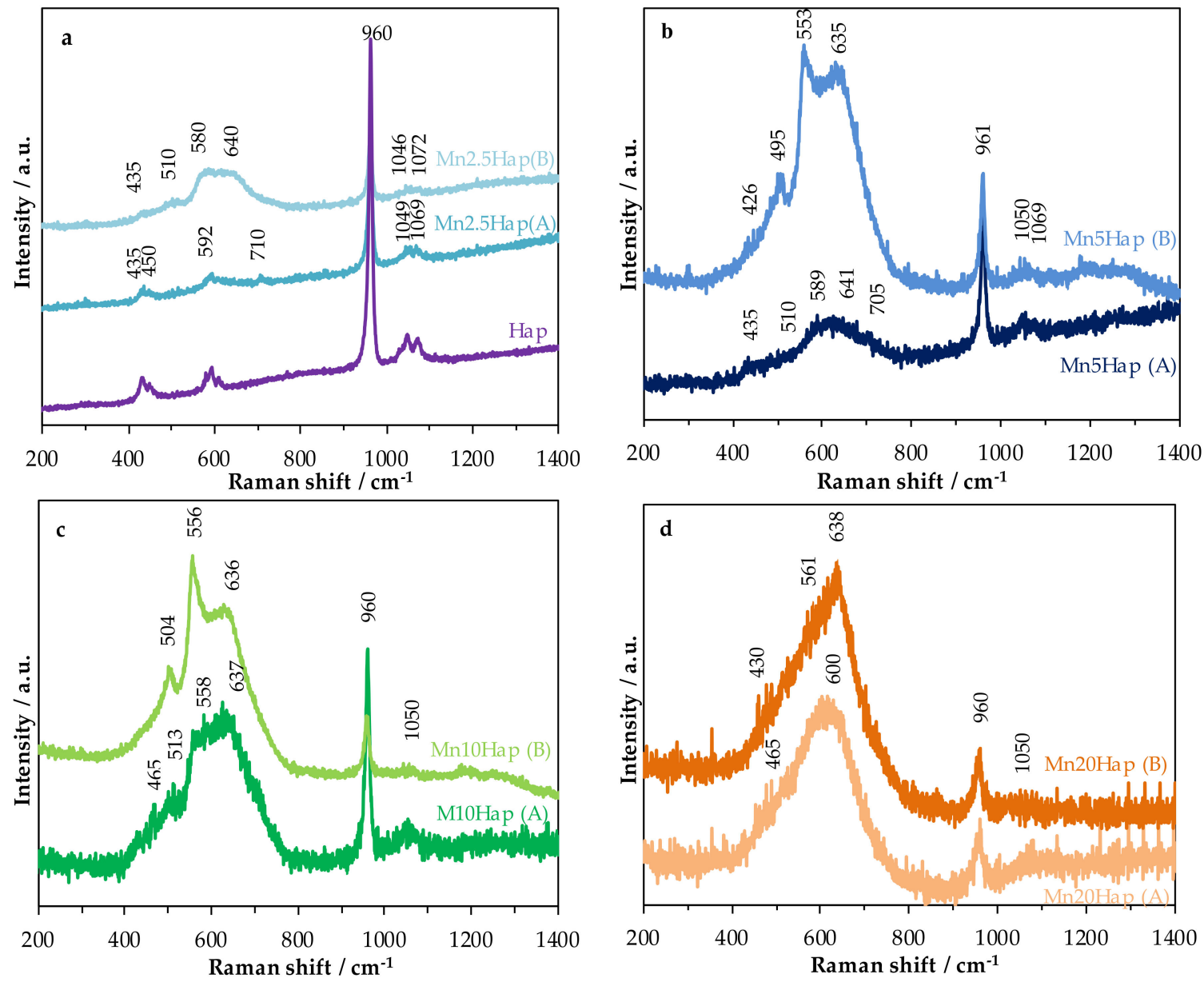

Figure 3. Cont. 


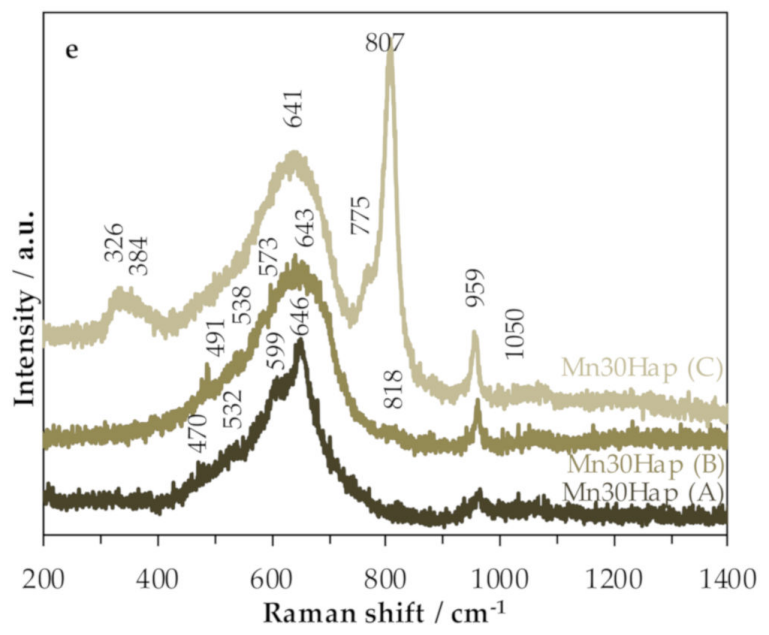

Figure 3. Raman spectra of (a) Hap and Mn2.5Hap; (b) Mn5Hap; (c) Mn10Hap; (d) Mn20Hap and; (e) Mn30Hap.

To investigate the effect of calcination on $\mathrm{MnOx}$ phase transformation and $\mathrm{NO}_{3}{ }^{-}$removal, in-situ Raman spectra were recorded for the precursor of Mn10Hap in a stream of $20 \% \mathrm{O}_{2} / \mathrm{He}$ while increasing the temperature from 30 to $500{ }^{\circ} \mathrm{C}$ with a heating rate of $5{ }^{\circ} \mathrm{C} / \mathrm{min}$ and keeping the final temperature for $1 \mathrm{~h}$ (see Figure S3a). At $100{ }^{\circ} \mathrm{C}$, the broad envelope in the $400-800 \mathrm{~cm}^{-1}$ range was fitted with lines at 496, 596 and $650 \mathrm{~cm}^{-1}$, suggesting the formation of $\varepsilon-\mathrm{MnO}_{2}$ like species Figure S3b. In the range of 200-1800 $\mathrm{cm}^{-1}$, we also observe that the line at $960 \mathrm{~cm}^{-1}$ was already defined as well as that of $\mathrm{NO}_{3}^{-}$ at $1050 \mathrm{~cm}^{-1}$. When increasing the temperature to $500{ }^{\circ} \mathrm{C}$, new lines appeared at 490 and $560 \mathrm{~cm}^{-1}$ whose intensity increases with time and with a shoulder at about $610 \mathrm{~cm}^{-1}$. No significant changes occurred at $500{ }^{\circ} \mathrm{C}$ and when returning to $30{ }^{\circ} \mathrm{C}$. The final Raman spectrum is compared to that at the beginning Figure S3c. It is evident that phase transformation occurs from $\varepsilon-\mathrm{MnO}_{2}$ like species into $\beta-\mathrm{MnOOH}$. Additionally, this transformation was accompanied by a decrease of the intensity of the line at $960 \mathrm{~cm}^{-1}$. With increasing the temperature, the partial disappearance of the line at $1050 \mathrm{~cm}^{-1}$ also takes place. The line intensity-T plot given in Figure $\mathrm{S} 3 \mathrm{~d}$ showed $\mathrm{NO}_{3}{ }^{-}$removal as a two steps process, one from $30{ }^{\circ} \mathrm{C}$ to $200{ }^{\circ} \mathrm{C}$ and the second one from $280{ }^{\circ} \mathrm{C}$ to $400{ }^{\circ} \mathrm{C}$. This can be explained by the initial removal of physisorbed $\mathrm{NO}_{3}{ }^{-}$and to some possible also by $\mathrm{NO}_{3}{ }^{-}$ions incorporated in the sub-surface of the hydroxyapatite lattice being more difficult to extract.

\subsection{Thermal Behavior of MnxHap Samples}

Thermal gravimetric analysis (TGA) and differential scanning calorimetry (DSC) traces combining with mass-spectroscopy (MS) of Hap, Mn10Hap, and Mn20Hap carried out in dry air are given in Figure $4 \mathrm{a}, \mathrm{b}$ and relevant results are collected in Table 2. The TG plot of Hap shows three weight loss steps corresponding to the release of water $(2.36 \%)$ and water/carbon dioxide $(2.45 \%$ and $2.73 \%)$ in agreement with results of on-line mass spectroscopy (see Figure S4). Three weight loss steps were also observed for Mn10Hap due to the release of water (2.78\%), water/carbon dioxide/nitrogen monoxide $(13.77 \%)$, and water/carbon dioxide (2.85\%). In comparison, 4 main losses steps were observed for Mn20Hap, whose total weight loss is 1.8 times higher than that of Mn10Hap. The main contributing release of $35.4 \%$ was mainly attributed to the release of adsorbed $\mathrm{H}_{2} \mathrm{O}$ and $\mathrm{NO}$ (not shown here). In agreement with previous studies [39-41], weight losses below $550{ }^{\circ} \mathrm{C}$ were ascribed to $\mathrm{H}_{2} \mathrm{O}_{\text {and }} \mathrm{CO}_{2}$ desorption from the Hap surface and those above $600{ }^{\circ} \mathrm{C}$ to $\mathrm{CO}_{2}$ released from the bulk of the material. In addition, in our case, the release of water starting from $900{ }^{\circ} \mathrm{C}$ was not negligible compared to the loss of $\mathrm{CO}_{2}$. Therefore, it is not possible to determine the part of weight loss due to $\mathrm{CO}_{2}$ departure and hence to evaluate the amount of $\mathrm{CO}_{3}{ }^{2-}$ moles per apatite formula. Conversely, such a calculation was possible in the work of Silvester et al. [39], where the weight loss starting from $900{ }^{\circ} \mathrm{C}$ and due to $\mathrm{H}_{2} \mathrm{O}$ release was much lower compared to that of $\mathrm{CO}_{2}$. The release of $\mathrm{H}_{2} \mathrm{O}$ was not as low compared to that 
of $\mathrm{CO}_{2}$. Furthermore, upon the addition of $\mathrm{Mn}$, some nitrate decomposition took place, rendering the evaluation of carbonates amount more difficult. The different postulated gas releases were supported by the exothermic effects displayed in the DSC curves in Figure 4b. Additionally, an endothermic effect was observed at $930{ }^{\circ} \mathrm{C}$ for Mn20Hap, which may be due to crystallization of the $\varepsilon-\mathrm{MnO}_{2}$.
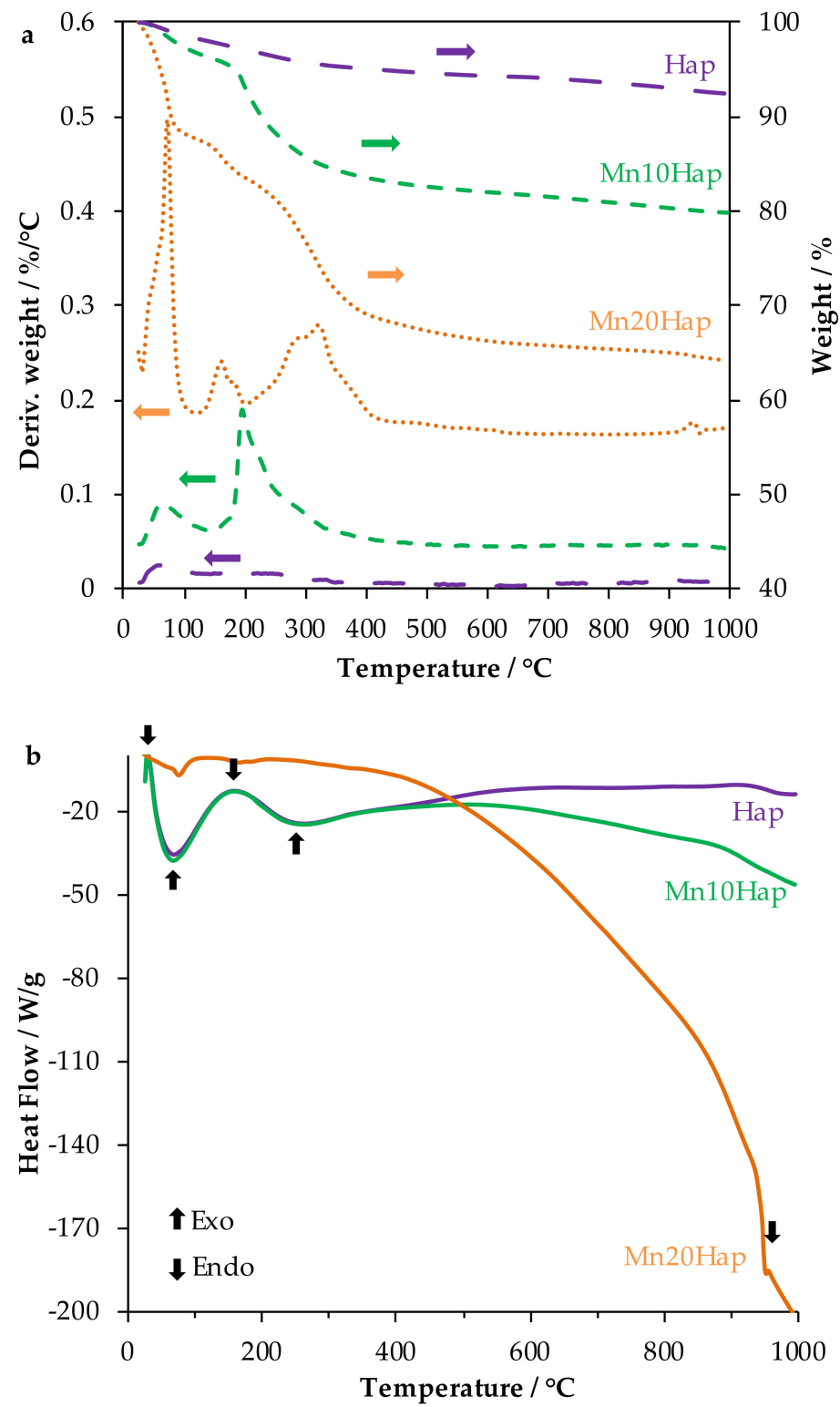

Figure 4. (a) TG and DT analysis and (b) DSC analysis for Hap, Mn10Hap, and Mn20Hap.

Table 2. Thermogravimetric analysis.

\begin{tabular}{|c|c|c|c|c|c|}
\hline \multirow[t]{2}{*}{ Catalysts } & \multicolumn{5}{|c|}{$\begin{array}{c}\text { Weight Loss } \\
\text { Temperature Range/ }{ }^{\circ} \mathrm{C} \\
\text { (Loss Percentage/\%) }\end{array}$} \\
\hline & I & II & III & IV & Total \\
\hline Hap & $\begin{array}{c}30-160 \\
(2.36)\end{array}$ & $\begin{array}{c}160-400 \\
(2.45)\end{array}$ & - & $\begin{array}{c}400-1000 \\
(2.73)\end{array}$ & $\begin{array}{c}30-1000 \\
(7.54)\end{array}$ \\
\hline Mn10Hap & $\begin{array}{c}30-160 \\
(2.78)\end{array}$ & $\begin{array}{c}160-550 \\
(13.77)\end{array}$ & 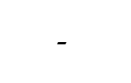 & $\begin{array}{c}550-1000 \\
(2.85)\end{array}$ & $\begin{array}{c}30-1000 \\
(19.4)\end{array}$ \\
\hline Mn20Hap & $\begin{array}{l}30-120 \\
(12.37)\end{array}$ & $\begin{array}{c}120-200 \\
(4.17)\end{array}$ & $\begin{array}{c}200-450 \\
(15.11)\end{array}$ & $\begin{array}{c}500-1000 \\
(4.19)\end{array}$ & $\begin{array}{c}30-1000 \\
(35.84)\end{array}$ \\
\hline
\end{tabular}




\subsection{HCHO Total Oxidation}

Figure 5 compares the formaldehyde conversion into $\mathrm{CO}_{2}$ as a function of temperature over the MnxHap materials thermally activated at $350{ }^{\circ} \mathrm{C}$. The relevant catalytic activity data are given in Table 3 . It is worth mentioning the absence of gaseous by-products in the course of the reaction showing, in that way, the selective transformation of $\mathrm{HCHO}$ into $\mathrm{CO}_{2}$ and $\mathrm{H}_{2} \mathrm{O}$. Formaldehyde conversion into $\mathrm{CO}_{2}$ based on $\mathrm{T}_{50}\left({ }^{\circ} \mathrm{C}\right.$ ) (the temperature at which $50 \%$ of $\mathrm{HCHO}$ has been converted into $\mathrm{CO}_{2}$ ) increased as follow: Mn2.5Hap (185) < Mn30Hap (163) Mn5Hap (158) Mn10Hap (158) < Mn20Hap (145). The catalysts could be ranked in a similar order after considering the activity data $\mathrm{T}_{10}$ and $\mathrm{T}_{90}$. We achieved $100 \%$ conversion of $\mathrm{HCHO}$ to $\mathrm{H}_{2} \mathrm{O}$ and $\mathrm{CO}_{2}$ at a temperature of $248^{\circ} \mathrm{C}$ on the most active catalyst. It was found that no clear relationship appears between formaldehyde conversion and Mn loading.

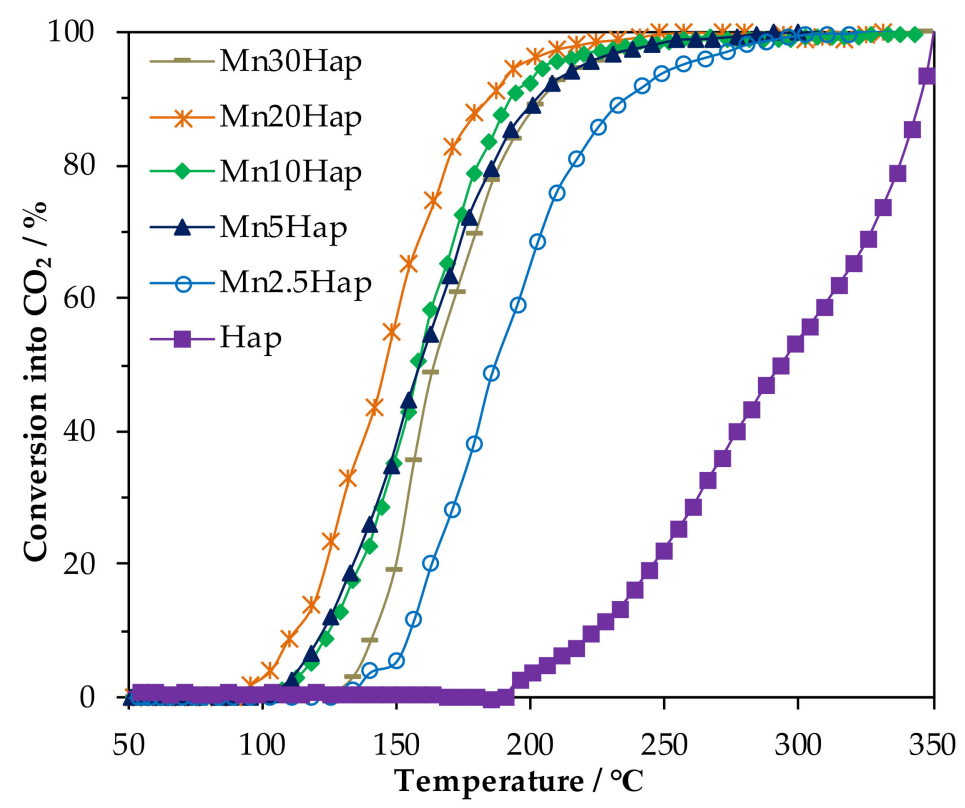

Figure 5. Conversion of $\mathrm{HCHO}$ into $\mathrm{CO}_{2}$ over MnxHap catalysts.

Table 3. Catalytic performances of the MnxHap catalysts.

\begin{tabular}{cccccc}
\hline Catalysts & $\mathbf{T}_{\mathbf{1 0}} /{ }^{\circ} \mathbf{C}$ & $\mathbf{T}_{\mathbf{5 0}} /{ }^{\circ} \mathbf{C}$ & $\mathbf{T}_{\mathbf{9 0}} /{ }^{\circ} \mathbf{C}$ & $\mathbf{E a} / \mathbf{k c a l ~} \mathbf{~ m o l}^{-\mathbf{1}}$ & $\mathbf{r}^{\mathbf{a}} / \mathbf{h}^{\mathbf{- 1}}$ \\
\hline Mn2.5Hap & 155 & 185 & 232 & 34.4 & 0.013 \\
Mn5Hap & 122 & 158 & 202 & 28 & 0.042 \\
Mn10Hap & 124 & 158 & 192 & 27.3 & 0.021 \\
Mn20Hap & 112 & 145 & 184 & 17.8 & 0.019 \\
Mn30Hap & 141 & 163 & 202 & 39.6 & 0.004 \\
\hline
\end{tabular}

a Expressed in the mole of $\mathrm{HCHO}$ transformed into $\mathrm{CO}_{2}$ per mole of Mn per hour estimated at $145^{\circ} \mathrm{C}$.

The normalized rate $\mathrm{r}$, expressed in the mole of $\mathrm{HCHO}$ transformed into $\mathrm{CO}_{2}$ per mole of $\mathrm{Mn}$ per hour, evaluated at $145^{\circ} \mathrm{C}$ as a function of $\mathrm{Mn}$ content is given in Figure 6 . The activity obeys the shape of a Volcano plot with a Mn5Hap catalyst showing the highest normalized rate of $0.042 \mathrm{~h}^{-1}$, which is twice as active as the Mn10Hap catalyst.

Carbon balance as a function of temperature displayed in Figure 7 in any case shows a convex asymmetric curve having one minimum. This indicates that formaldehyde is retained on the surface of the catalysts. The high temperature part of the curve which corresponds to the progressive decrease of the carbon balance down to the minimum value close to zero can be explained by a progressive retention of formaldehyde, probably as formate, on the catalytic surface [42]. The low temperature branch of the curve is consistent with the detection of $\mathrm{HCHO}$ as an off gas whose concentration increases with time. 


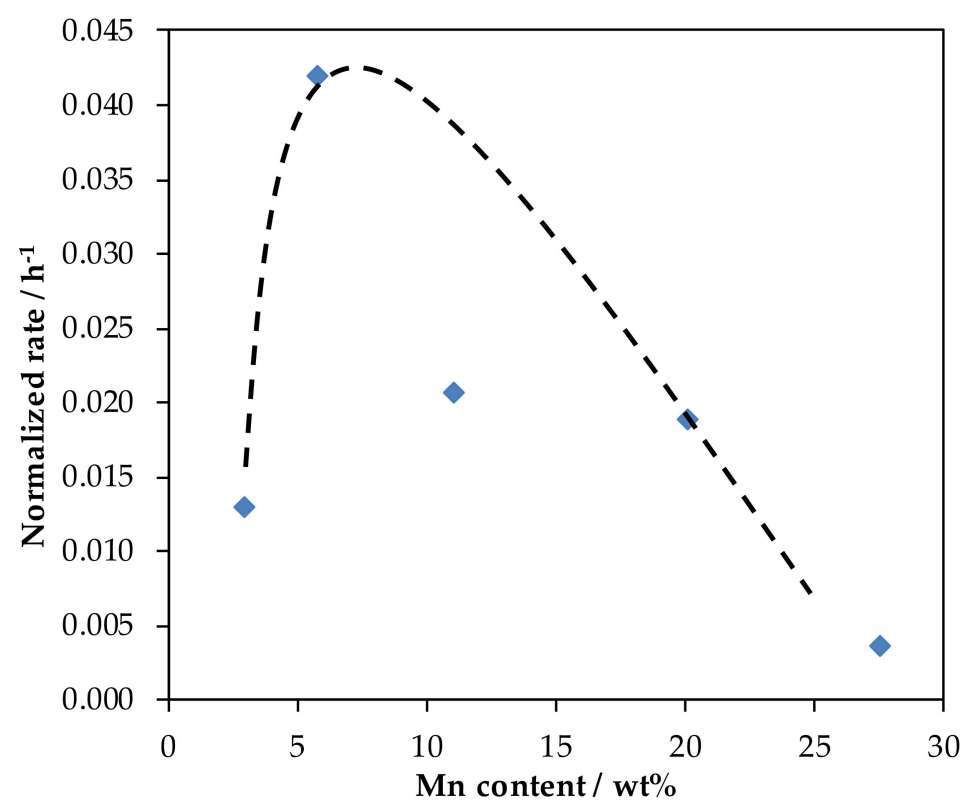

Figure 6. Normalized rate as a function of the Mn content (wt\%).

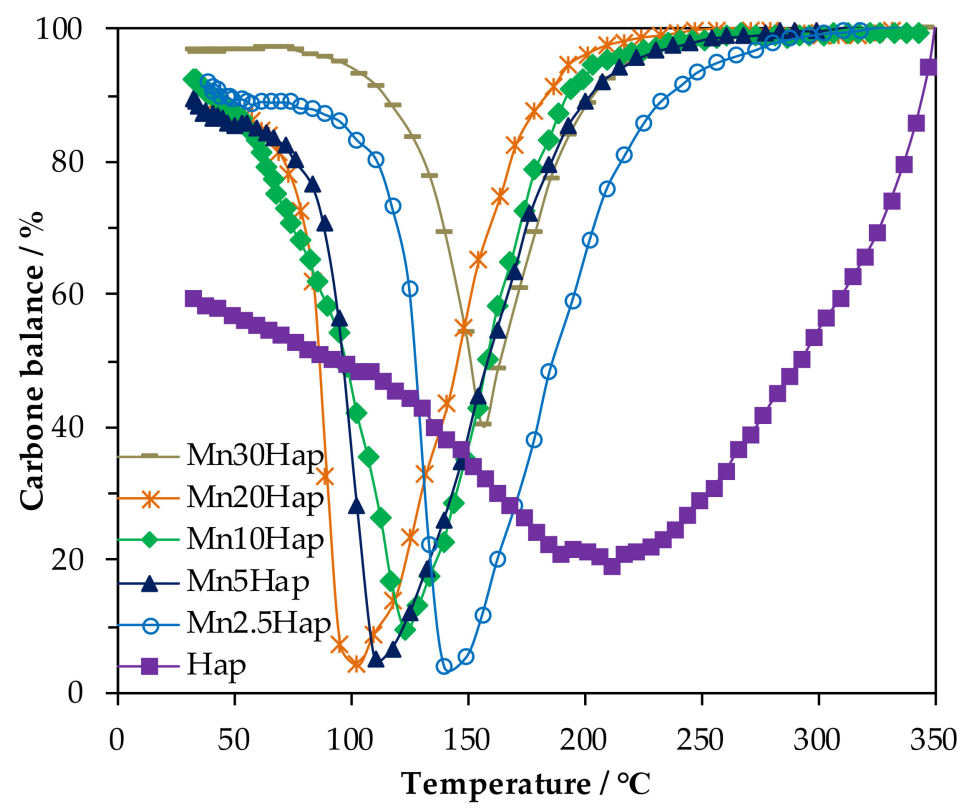

Figure 7. Carbon balance as a function of temperature for MnxHap catalysts.

However, the initial concentration of formaldehyde at low temperature is not retrieved due to physical adsorption of formaldehyde on the catalyst surface. Calculation of the area under the curve by integration allows for estimating the percentage of carbon deficiency, which ranges between 17 and $20 \%$. In order to get additional insight about the thermal behavior of formaldehyde-based species retained by the catalysts, MnxHap samples $(x=5 ; 10 ; 30)$ were subjected to a calcination step after the catalytic test was performed in $\mathrm{O}_{2} / \mathrm{He}(20 / 80)$ from $25^{\circ} \mathrm{C}$ to $300^{\circ} \mathrm{C}$, and the pertinent data are given in Table 4. Figure 8 displays the evolution of formaldehyde and $\mathrm{CO}_{2}$ as a function of temperature over the catalysts. Desorption of formaldehyde is observed on all the catalyst surfaces at $25^{\circ} \mathrm{C}$. It rapidly decreases down to zero at about $140{ }^{\circ} \mathrm{C}$. 
Table 4. Carbon balance levels.

\begin{tabular}{cccccc}
\hline Catalysts & $\mathbf{C B}$ a $\%$ & $\mathbf{H C H O} / \mu \mathbf{m o l}$ & $\mathbf{C O}_{2} / \mu \mathbf{m o l}$ & $\mathbf{C B}^{\mathbf{b}} / \%$ & $\mathbf{C O}_{2} / \mathbf{M n}$ \\
\hline Mn5Hap & 80 & 17 & 42 & 92 & 0.2 \\
Mn10Hap & 82 & 10 & 48 & 93 & 0.12 \\
Mn30Hap & 83 & 2.2 & 11 & 86 & 0.01 \\
\hline
\end{tabular}

${ }^{a}$ Carbon balance owing to Equation (2); ${ }^{\mathrm{b}}$ Corrected Carbon Balance considering the molar amount of $\mathrm{HCHO}$ and $\mathrm{CO}_{2}$ produced during the calcination performed after the test.
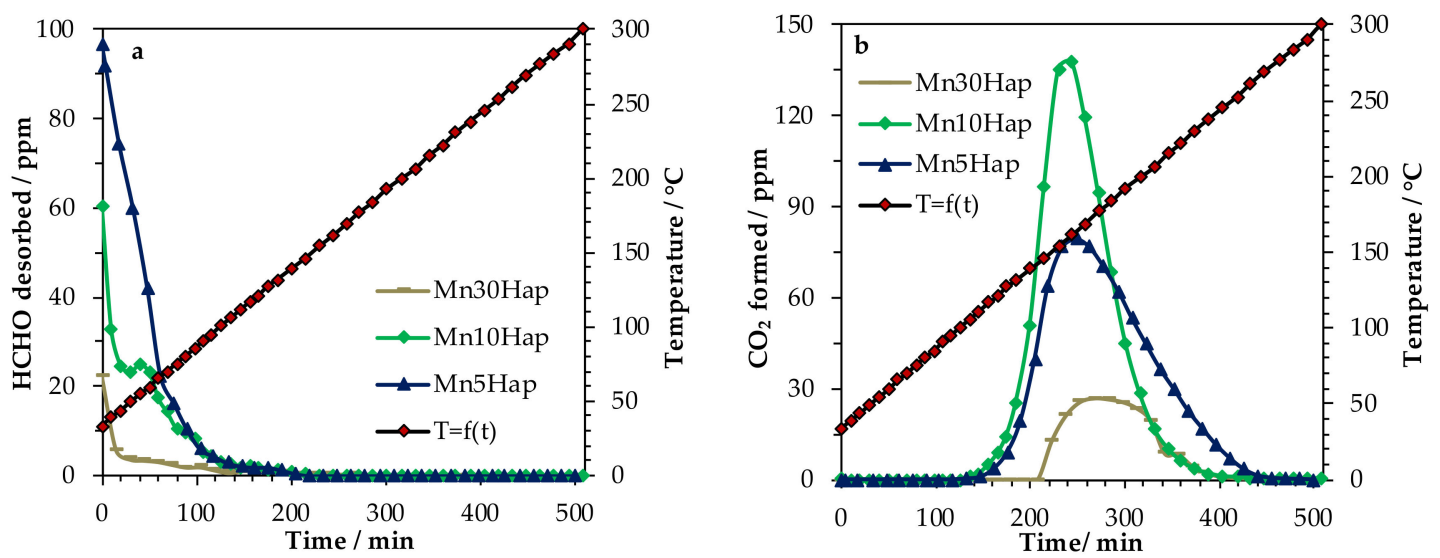

Figure 8. (a) Amount of desorbed $\mathrm{HCHO}$ and (b) $\mathrm{CO}_{2}$ production as a function of temperature for MnxHap catalysts.

Carbon dioxide production occurred in a single broad peak, between $100{ }^{\circ} \mathrm{C}\left(140{ }^{\circ} \mathrm{C}\right.$; Mn30Hap $)$ and $250{ }^{\circ} \mathrm{C}$, with a maximum located at $155^{\circ} \mathrm{C}$ (Mn10Hap), $160^{\circ} \mathrm{C}$ (Mn5Hap) and $175^{\circ} \mathrm{C}$ (Mn30Hap). The amount of $\mathrm{CO}_{2}(\mu \mathrm{mol})$ released increased as follows: 11 (Mn30Hap) $<42$ (Mn5Hap) < 48 (Mn10Hap). The molar ratio of $\mathrm{CO}_{2}$ produced to Mn content, which is believed to be proportional to the dispersion of the active phase, was determined for the different samples. The $\mathrm{CO}_{2} / \mathrm{Mn}$ estimated to be 0.20 for Mn5Hap solid was about 1.6 times and 20 times higher than those estimated for Mn10Hap and Mn30Hap catalysts.

The apparent activation energy $E_{a}$ values for formaldehyde oxidation over the MnxHap catalysts were calculated from the Arrhenius plots and are shown in Figure 9. The apparent activation energies are in the range of those found in the literature $[43,44]$. The $\mathrm{E}_{\mathrm{a}}$ value depends on the Mn loading in the sample taking values of ca. $17.8 \mathrm{kcal} \mathrm{mol}^{-1}$ for Mn20Hap, $28 \mathrm{kcal} \mathrm{mol}^{-1}$ for Mn5Hap and Mn10Hap, $34.4 \mathrm{kcal} \mathrm{mol}^{-1}$ for Mn2.5Hap, and $39.6 \mathrm{kcal} \mathrm{mol}^{-1}$ for Mn30Hap. Over the Mn20Hap catalyst, the reaction is easier to activate, which may provide evidence that the reaction pathway was changed.

The main reason behind better catalytic performances was the decrease of the activation energy. However, the pre-exponential factor A in the Arrhenius law played also a role. Mn5Hap presents a higher activation energy than Mn20Hap, yet this fact could be compensated for by a higher value of A, which refers to the frequency of collisions. According to the Arrhenius equation, the calculated value of the pre-exponential factor A for the Mn5Hap catalyst is equal to $1.1785 \times 10^{15}$ higher than that of Mn20Hap $5.589 \times 10^{9}$; this indicates that Mn5Hap is a better catalyst with a higher Mn dispersion.

The catalytic properties $\left(\mathrm{T}_{50(\mathrm{CO})}\right)$ of the supported $\mathrm{MnOx}$ phases in the total oxidation of formaldehyde are listed in Table 5. It could be found that our systems are among the active ones found in the literature. 


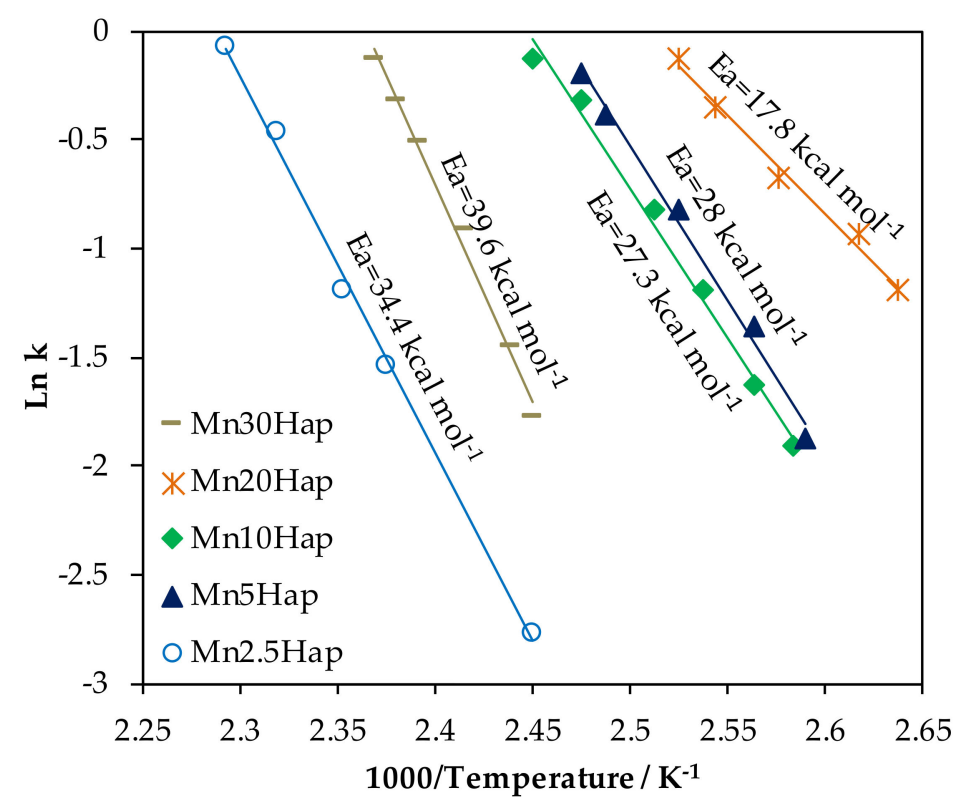

Figure 9. Arrhenius plots for $\mathrm{HCHO}$ oxidation over MnxHap catalysts.

Table 5. Catalytic performances over MnOx based catalysts given in the literature.

\begin{tabular}{|c|c|c|c|c|c|}
\hline Catalyst & $\begin{array}{c}\mathrm{Mn} \\
(\mathbf{w t} \%)\end{array}$ & $\begin{array}{l}\text { HCHO } \\
\text { (ppm) }\end{array}$ & $\begin{array}{c}\text { GHSV (h-1) } \\
\left(\text { VHSV) }\left(\mathrm{L} \mathrm{g} \mathrm{gat}^{-1} h^{-1}\right)\right.\end{array}$ & $\begin{array}{l}\mathrm{T}_{50(\mathrm{CO} 2)} \\
\left({ }^{\circ} \mathrm{C}\right)\end{array}$ & Reference \\
\hline Mn20Hap & 20 & & & 145 & \\
\hline Mn10Hap & 11 & 120 & $(30)$ & 158 & This work \\
\hline Mn5Hap & 5.8 & & & 158 & \\
\hline $\mathrm{MnOx} / \mathrm{PG}-\mathrm{MN}{ }^{\mathrm{a}}$ & 8.9 & 1200 & $(60)$ & 162 & [43] \\
\hline $\mathrm{Mn} / \gamma-\mathrm{Al}_{2} \mathrm{O}_{3}$ & 18.2 & 5300 & (120) & $205 *$ & [45] \\
\hline $\mathrm{MnO}_{2} /$ Cellulose fiber & $\begin{array}{c}8.86 \\
3.2\end{array}$ & 100 & 50,000 & $\begin{array}{l}88 * \\
140\end{array}$ & [46] \\
\hline $\mathrm{Mn} / \mathrm{Pal}{ }^{\mathrm{b}}$ & 10.3 & 1000 & 32,500 & 231 & [47] \\
\hline $\mathrm{Mn} / \mathrm{PG}$ & 15 & 300 & 20,000 & $162 *$ & [48] \\
\hline $\begin{array}{l}\text { Mnx/DM-AO }{ }^{\mathrm{C}} \\
\mathrm{Mnx} / \mathrm{DM}^{-M T}{ }^{\mathrm{c}}\end{array}$ & $\begin{array}{l}19.8 \\
18.5\end{array}$ & 180 & $(0.06)$ & $\begin{array}{l}48.8^{*} \\
45.5^{*}\end{array}$ & [49] \\
\hline MN-MnOx-Halloysite & 7.6 & 1500 & $(60)$ & $\sim 210$ & [50] \\
\hline
\end{tabular}

a MnOx/PG-MN: palygorskite supported manganese oxide with manganese nitrate (MN) as precursor; b Pal: palygorskite is a natural nanorod-like clay mineral; ${ }^{\mathrm{c}}$ Diatomite-supported birnessite-type $\mathrm{MnO}_{2}\left(\delta-\mathrm{MnO}_{2}\right)$ synthesized through an in-situ reduction method by methanol (Mnx/DM-MT) and hydrothermal reduction method by ammonium oxalate (Mnx/DM-AO), respectively; * Conversion of HCHO.

\subsection{Diffuse Reflectance Infrared Fourier Transform Spectroscopy (DRIFT) Experiment at Room Temperature}

DRIFT experiments have been performed in order to determine the nature of the adsorbates formed after reaction. DRIFT experiments have been conducted at room temperature for the used catalyst (Mn10HapU). For a comparison purpose, the fresh catalyst Mn10Hap was also tested. The obtained results are plotted in Figure 10a and the difference between the two spectra are displayed in Figure 10b. Four intense bands related to formate species adsorbed on the catalyst surface at $2858\left(v_{\mathrm{CH}}\right), 1593$ (asym $\left.v_{\mathrm{OCO}}\right), 1382\left(\delta_{\mathrm{CH}}\right)$, and $1356 \mathrm{~cm}^{-1}$ (sym $\left.v_{\mathrm{OCO}}\right)$ were observed. 


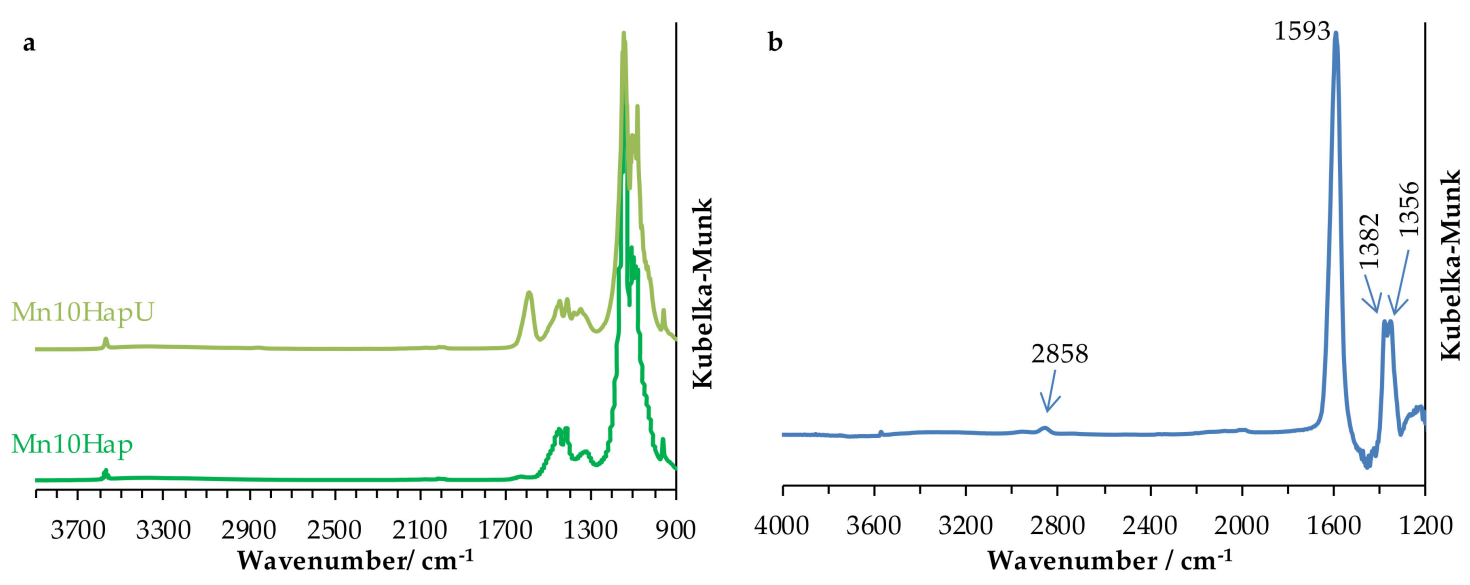

Figure 10. (a) Diffuse Reflectance Infrared Fourier Transform spectroscopy (DRIFT) spectra of Mn10Hap sample before and after the catalytic test (Mn10HapU) and (b) Difference between the two recorded spectra.

\subsection{TD-FTIR}

Original spectra were recorded over the whole range of transparency of the Hap self-supporting pellet $\left(4000-1250 \mathrm{~cm}^{-1}\right)$.

The typical FTIR spectrum of the formaldehyde saturated Mn10HapF sample is presented in Figure 11. In the $v(\mathrm{OH})$ region, the main band was observed at $3571 \mathrm{~cm}^{-1}$. It was assigned to both the contributions of structural $\mathrm{OH}^{-}$groups located inside the channels $\left(\mathrm{bulk} \mathrm{OH}^{-}\right.$) and to structural $\mathrm{OH}^{-}$emerging at the surface (surface $\mathrm{OH}^{-}$), as can be seen in Figure 11a. The broad multicomponent contribution observed at $1550-1300 \mathrm{~cm}^{-1}$ Figure $11 \mathrm{~b}$ was assignable to the presence of carbonate groups. The most intense contributions at 1448 and $1415 \mathrm{~cm}^{-1}$, as well as the weak contribution at $1500 \mathrm{~cm}^{-1}$, were assigned to the incorporation of bulk carbonates located in the A sites (corresponding to substitution of the $\mathrm{OH}^{-}$groups inside the channels) during the preparation. Therefore, at low temperature, the production of $\mathrm{CO}_{2}$ might arise from the $\mathrm{CO}_{2}$ desorbing from $\mathrm{OH}^{-}$and $\mathrm{O}^{2-}$ basic sites, formed from the reversible substitution A-type on the surface. The positions and intensities of the bands relative to the bulk carbonates located in the A sites were not affected upon thermal treatment at up to $500{ }^{\circ} \mathrm{C}$. The $\mathrm{C} 2 \mathrm{v}$ formate, which gives two modes, was assigned to the asymmetric and symmetric $\mathrm{C}-\mathrm{O}$ stretching (peaks asym and sym). The asymmetric $\mathrm{C}=\mathrm{O}$ stretching mode was predicted at $1617 \mathrm{~cm}^{-1}$ and $1584 \mathrm{~cm}^{-1}$, while the symmetric $\mathrm{C}=\mathrm{O}$ stretching mode was predicted at $1308 \mathrm{~cm}^{-1}$ and $1313 \mathrm{~cm}^{-1}$ in interactions with the Hap (001), and the water reacted to WR(010) surfaces [51]. An intense broad band was observed at $1593 \mathrm{~cm}^{-1}$ showing an asymmetry on the high frequency side. A de-convolution of the spectral profile was carried out considering two components. The bands were in really good agreement with frequencies calculated for FA_Ca1,Ca3 $\left(1617 \mathrm{~cm}^{-1}\right)$ and for FA-(010)WR species $\left(1583 \mathrm{~cm}^{-1}\right)$, respectively. The bands at $1356(v \mathrm{~s}(\mathrm{COO}-)), 1382(\delta(\mathrm{CH}))$, 1593 (vas(COO-)) and $2858(v(\mathrm{C}-\mathrm{H}))$ have been previously attributed to adsorbed formate species [10]. Increasing the temperature induced a decrease of the bands of formate species, accompanied by a concomitant decrease of the band at $3571 \mathrm{~cm}^{-1}$, suggesting that the oxidation of formate consumed $\mathrm{OH}$ groups. The almost formate bands disappearance at $344^{\circ} \mathrm{C}$ coincided with the net increase of $\mathrm{CO}_{2}$ production in the gas phase Figure S5. A new band was also detected at $260{ }^{\circ} \mathrm{C}$ located at $3542 \mathrm{~cm}^{-1}$ Figure 11a resulting from dehydration of part of the material due to the consumption of $\mathrm{OH}^{-}$groups for the benefit of $\mathrm{O}^{2-}$, whose intensity increases as the temperature increases. 

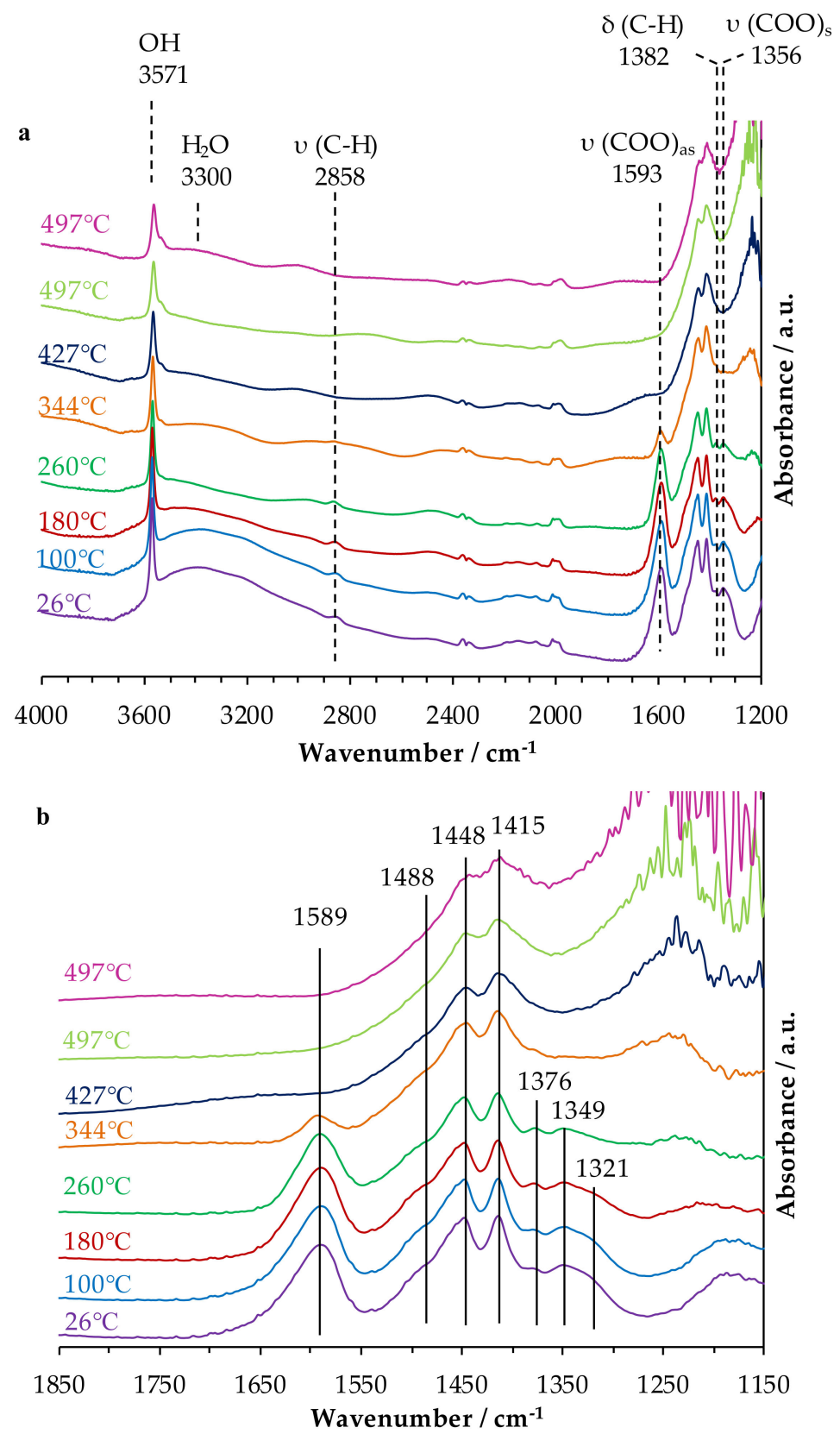

Figure 11. IR spectra of the Mn10HapF sample after $\mathrm{HCHO}$ adsorption and heating under $\mathrm{He}(\mathbf{a})$ in the $1200-4000 \mathrm{~cm}^{-1}$ and (b) $1150-1850 \mathrm{~cm}^{-1}$ window.

\subsection{Moisture Effect, Regeneration Step and Stability Test}

Figure 12 shows the effect of $\mathrm{H}_{2} \mathrm{O}$ on $\mathrm{HCHO}$ conversion into $\mathrm{CO}_{2}$ with time on stream at $135{ }^{\circ} \mathrm{C}$ over the Mn10Hap catalyst. After an induction period of $4 \mathrm{~h}$, the catalyst reached a conversion of $\mathrm{HCHO}$ into $\mathrm{CO}_{2}$ of $80 \%$ in dry air. When adding water $(\mathrm{RH}=25 \%)$ in the feed, the HCHO conversion increased up to $92 \%$ at the early stage before rapidly decreasing to reach $78 \%$. Once water was stopped, we observed a slight linear deactivation with time $(67 \%$ after $13 \mathrm{~h})$. The new addition of water in the feed $(\mathrm{RH}=50 \%)$ induced an instantaneous raise in conversion (close to $97 \%$ ) followed by a rapid decrease before reaching a quasi-stationary state $(71 \%$ after $4 \mathrm{~h})$. Stopping water induces a lowering activity with a conversion of $63 \%$ after $7 \mathrm{~h}$ on stream. This shows that the presence of moisture has a beneficial effect on the activity of the catalyst. In fact, water was first adsorbed on the surface of the catalyst enhancing the adsorption of $\mathrm{HCHO}$ on the catalyst by forming hydrogen bonding with $\mathrm{HCHO}$ (the $\mathrm{O}$ atom of $\mathrm{HCHO}$ was adsorbed on the $\mathrm{H}$ atom of $\mathrm{HOH}$ sites) [52,53]. Adsorbed $\mathrm{HCHO}$ 
would be oxidized by surface active oxygen (hydroxyl groups bonded within the channel $\mathrm{Ca}^{2+}$ ) [17]. The consumed surface $\mathrm{OH}$ was then compensated for by water. This process increases and enhances the activity of the catalyst for the $\mathrm{HCHO}$ oxidation.

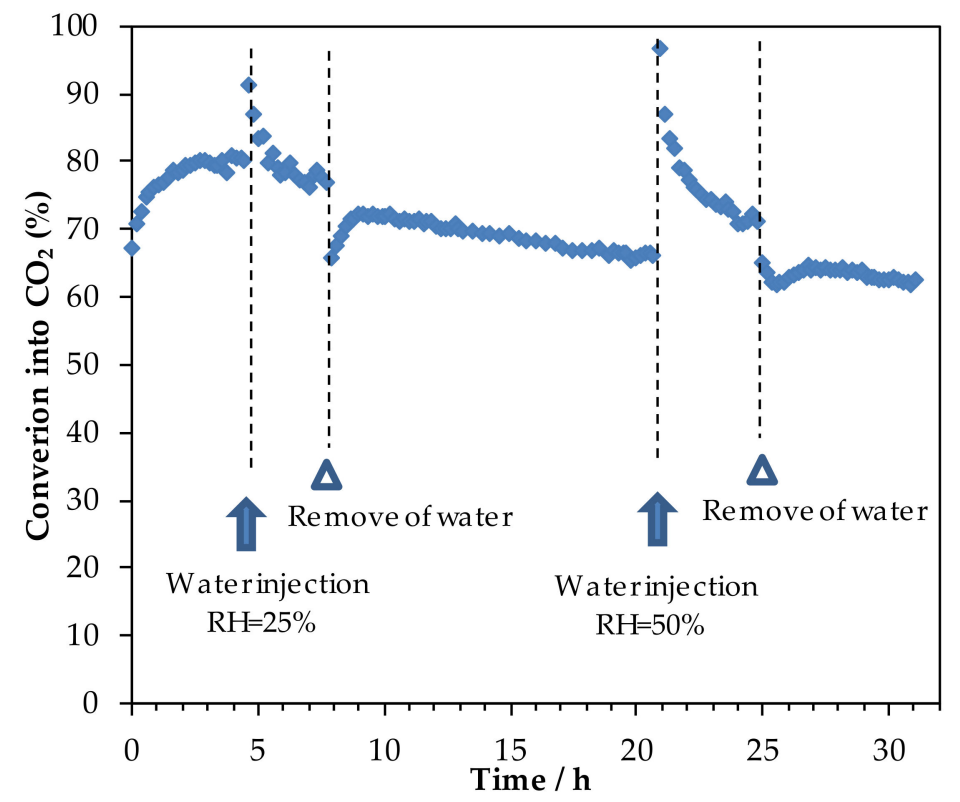

Figure 12. Effect of $\mathrm{H}_{2} \mathrm{O}$ on $\mathrm{HCHO}$ conversion over the Mn10Hap catalyst: $135^{\circ} \mathrm{C}, \mathrm{HCHO}=110 \mathrm{ppm}$ in moist air, $\mathrm{RH}=25 \%$ and $50 \%$, VHSV $=500 \mathrm{~mL} \mathrm{~g}_{\text {cat }}{ }^{-1} \mathrm{~h}^{-1}$.

Regeneration Step of the Catalyst

After the stability test, a calcination at $350^{\circ} \mathrm{C}$ for $2 \mathrm{~h}$ and at $135^{\circ} \mathrm{C}$ for $5 \mathrm{~h}$ was performed on the used Mn10Hap catalyst. In order to check the efficiency of such a treatment, the catalytic performance of the calcined Mn10Hap was assessed based on the amount of time on stream, as can be seen in Figure 13. After an induction period of about $7 \mathrm{~h}$, the activity of the catalyst was retrieved $\approx 80 \%$ ) and then a slight deactivation was observed on stream.
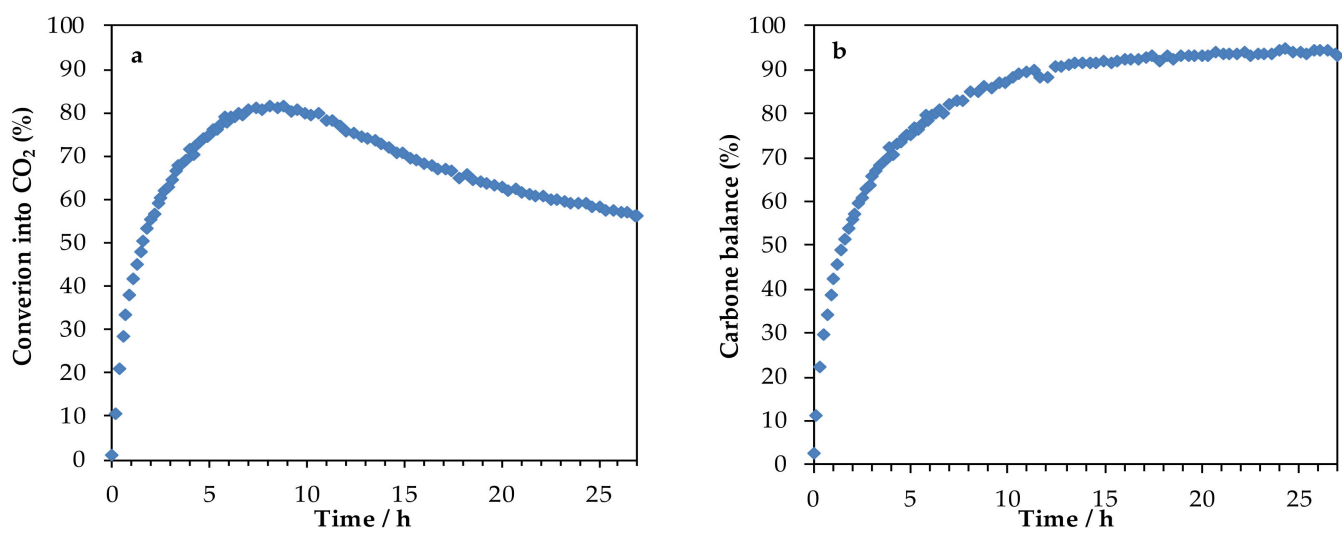

Figure 13. (a) Stability test performed for $27 \mathrm{~h}$ at $135^{\circ} \mathrm{C}$ after the regeneration step and (b) Carbon balance over the Mn10Hap catalyst.

\section{Materials and Methods}

\subsection{Synthesis of the Hap Support and Supported Mn Catalysts}

The Hap support material was synthesized according to a previous procedure [39] was calcined at $400{ }^{\circ} \mathrm{C}$ for $4 \mathrm{~h}$ prior to impregnation. The Hap supported manganese catalysts were prepared using 
the wet impregnation method, as was already reported [19]. To sum up, samples loaded with 2.5, 5, 10,20 , and $30 \mathrm{Mn} w \mathrm{wt} \%$ (using $\mathrm{MnO}_{2}$ as the basis) were synthesized using $\mathrm{Mn}\left(\mathrm{NO}_{3}\right)_{2} \cdot 4 \mathrm{H}_{2} \mathrm{O}$ (Sigma Aldrich, Darmstadt, Germany, purity: $97 \%$ ) as a Mn precursor. A total of $50 \mathrm{~mL}$ of the appropriate aqueous precursor solution $\left(0.16 \mathrm{~mol} \mathrm{~L}^{-1}\right)$ was added to Hap $(3.4 \mathrm{~g})$ and stirred at $60{ }^{\circ} \mathrm{C}$ using a rotary evaporator. The water was then removed under reduced pressure. The solids were then dried at $80^{\circ} \mathrm{C}$ for $20 \mathrm{~h}$ and calcined for $4 \mathrm{~h}$ at $400{ }^{\circ} \mathrm{C}$ under air flow. The resulting powders were denoted as MnxHap for which $x$ represents the Mn content $(x=2.5,5,10,20$, and $30 \mathrm{wt} \%)$.

\subsection{Characterization of the Materials}

Mn elemental analysis was performed by using inductively coupled plasma spectroscopy- optical emission spectroscopy (ICP-OES). Analyses were carried out at the REALCAT platform (Lille University) using an Agilent Technologies 700 Series spectrometer (Agilent, Mulgrave, Vic, Australia). For analysis, $20 \mathrm{mg}$ of the samples were dissolved in $50 \mathrm{~mL}$ of aqua regia solution.

The textural properties (specific surface area and pore volume) of the solids were determined using the physisorption technique with a Micromeritics Tristar II analyzer (Micromeritics, Merignac, France). Before $\mathrm{N}_{2}$ adsorption, the materials were outgassed at $200{ }^{\circ} \mathrm{C}$ for $4 \mathrm{~h}$ under vacuum.

Powder XRD data were recorded using a Bruker AXS D8 Advance diffractometer (Madison, WI, USA) working in a Bragg-Brentano geometry. The instrument was equipped with a Lynx Eye Super Speed detector. Data were collected at room temperature using the $\mathrm{Cu} \mathrm{K} \alpha$ line in a $2 \theta$ range from 10 to $50^{\circ}$ with a step size of $0.02^{\circ}$ and a $10 \mathrm{~s}$ counting time per step. $\mathrm{LaB}_{6}$ was used as a standard to derive the instrument resolution. The Fullprof Suite program was used for Rietveld refinement on the Hap and MnxHap samples. Additionally, the mean crystallite size of Mn oxide phase was calculated by using the Scherrer formula $(D=\lambda / \beta \cos \theta$ in which $\lambda$ is the wavelength, $\beta$ is the integral breadth, and $\theta$ is the peak position).

Fourier-Transform Transmission Infrared (FT-IR) spectra were recorded at room temperature using a Nicolet 460 Fourier transform infrared spectrometer (Thermo Fisher Scientific, Waltham, MA, USA) from $220 \mathrm{~cm}^{-1}$ to $4000 \mathrm{~cm}^{-1}$. The spectral resolution was $4 \mathrm{~cm}^{-1}$. KBr pellets were prepared by mixing intimately $1 \mathrm{mg}$ of powdered sample with $60 \mathrm{mg}$ of dried KBr. All FT-IR spectra are an average of 256 scans.

The Raman spectra of the samples, were recorded at room temperature using a Raman spectrometer (Horiba Jobin Yvon Labram HR800, Villeneuve d'Ascq, France) equipped with a Peltier-cooled detector. The exciting light source was the $488 \mathrm{~nm}$ line of an $\mathrm{Ar}^{+}$-ion laser and the spectral resolution was $\pm 1.5 \mathrm{~cm}^{-1}$. Laser power was $0.4 \mathrm{~mW}$ and acquisition time was about $100 \mathrm{~s}$. The presented spectra are the average of 3 scans. The Raman spectrometer was calibrated using the silicon Raman line at $520.6 \mathrm{~cm}^{-1}$.

Thermo gravimetric analysis (TGA) was performed using a Thermal Analysis instrument (SDT 2960 DSC-TGA X, Paris, France) connected to a mass spectrometer (Omnistar, Pfeiffer Vacuum, Asslar, Karlsruhe, Germany), on $10 \mathrm{mg}$ of sample. The weight loss was recorded under $20 \mathrm{vol} \% \mathrm{O}_{2} / \mathrm{He}$, at a heating rate of $5^{\circ} \mathrm{C} \cdot \mathrm{min}^{-1}$ from room temperature to $1000{ }^{\circ} \mathrm{C}$.

\subsection{Catalytic Oxidation of Formaldehyde}

Catalytic tests were performed with $0.200 \mathrm{~g}$ of catalyst loaded in a glass tubular reactor (I.D. $=10 \mathrm{~mm}$ ). The total flow rate was fixed at $100 \mathrm{~mL} \mathrm{~min}^{-1}$, with $120 \mathrm{ppmv}$ inlet $\mathrm{HCHO}$ in air flow, which corresponds to a Volume Hourly Space Velocity (VHSV) of $500 \mathrm{~mL} \mathrm{~g} \mathrm{~g}^{-1}$. Generation of formaldehyde in gas flow was performed using a permeation system from VICI Metronics (Dynacalibrator Model 150, Poulsbo, WA, USA), loaded with paraformaldehyde. Gas phase formaldehyde concentration was adjusted through control of the permeation chamber temperature at a selected gas flow rate. Before catalytic reaction, the catalyst was calcined in dry air at $350{ }^{\circ} \mathrm{C}\left(5^{\circ} \mathrm{C} \mathrm{min}{ }^{-1}\right.$, total flow rate $=100 \mathrm{~mL} \mathrm{~min}^{-1}$ ) for $2 \mathrm{~h}$. The catalyst was then submitted to the reactive gas mixture for $1 \mathrm{~h}$ at $350{ }^{\circ} \mathrm{C}$ to allow the temperature to decrease at a rate of $0.5^{\circ} \mathrm{C} \mathrm{min}-1$. Products and reactants were 
separated and quantified by using on line gas chromatography (Varian CP4900 Micro-GC, Palo Alto, CA, USA) equipped with a TCD and CP-Sil 5 CB column for separation $(8 \mathrm{~m})$. The HCHO conversion into $\mathrm{CO}_{2}(\mathrm{X})$ and carbon balance (CB) were calculated according to Equations (1) and (2).

$$
\begin{gathered}
\mathrm{X}(\%)=\frac{\left[\mathrm{CO}_{2}\right]_{\mathrm{out}}}{[\mathrm{HCHO}]_{\mathrm{in}}} \times 100 \\
\mathrm{CB}(\%)=\frac{\left[\mathrm{CO}_{2}\right]_{\mathrm{out}}+[\mathrm{HCHO}]_{\mathrm{out}}}{[\mathrm{HCHO}]_{\text {in }}} \times 100
\end{gathered}
$$

$\left[\mathrm{CO}_{2}\right]_{\text {out }},[\mathrm{HCHO}]_{\text {in, }}$, and $[\mathrm{HCHO}]_{\text {out }}$ were the $\mathrm{CO}_{2}$ concentration in the outlet gas and the $\mathrm{HCHO}$ concentration in both the inlet and outlet gas, respectively.

The rate of $\mathrm{HCHO}$ conversion was calculated using the formula:

$$
r=\frac{\mathrm{F} \times \mathrm{X}}{\mathrm{n}_{\mathrm{Mn}}}
$$

where $r$ was the rate of $\mathrm{HCHO}$ transformed into $\mathrm{CO}_{2}$ expressed in mole of reacted $\mathrm{HCHO}$ per mole of manganese and per hour. $\mathrm{F}$ was the normalized flow rate $\left(\mathrm{T}=25^{\circ} \mathrm{C}\right)$ of $\mathrm{HCHO}$ in mole per hour and $\mathrm{n}_{\mathrm{Mn}}$ was the molar amount of manganese.

The apparent energy of activation $\left(\mathrm{E}_{\mathrm{a}}\right)$ of the catalytic reaction for the different catalysts was estimated for a $\mathrm{HCHO}$ conversion into $\mathrm{CO}_{2}$ below $20 \%$ so that differential reaction conditions could be assumed with negligible heat and mass-transfer effects. After assuming that a reaction which was first and zero-order with respect to $\mathrm{HCHO}$ and to $\mathrm{O}_{2}$ (large excess) respectively, the apparent rate constant $\mathrm{k}_{\mathrm{APP}}$ was calculated using the formula $\mathrm{k}_{\mathrm{APP}}=-\ln (1-\mathrm{X}) / \tau(\tau$ : residence time based on the catalyst volume $)$. $\mathrm{E}_{\mathrm{a}}$ values were obtained by plotting $\ln \left(\mathrm{k}_{\mathrm{APP}}\right)$ versus $1 / \mathrm{T}$.

\subsection{DRIFT Experiment at Room Temperature}

DRIFT spectra of fresh Mn10Hap (before the catalytic test) and the used one Mn10HapU (after the catalytic test) were recorded in a Nicolet 6700-FTIR (Thermo Electron Corporation, Waltham, MA, USA) equipped with a smart collector and a liquid $\mathrm{N}_{2}$ cooled MCT/A detector. The samples (about $30 \mathrm{mg}$ ) for study were finely grounded and placed in a ceramic crucible. All spectra were measured at room temperature with a resolution of $4 \mathrm{~cm}^{-1}$ and accumulating 256 scans. A background spectrum was subtracted from each spectrum, respectively.

\subsection{Adsorption of Formaldehyde}

The Mn10Hap solid ( $\approx 100 \mathrm{mg})$ was exposed to flowing air $\left(100 \mathrm{~mL} \mathrm{~min}^{-1}\right)$ at $150{ }^{\circ} \mathrm{C}$ for $20 \mathrm{~min}$ $\left(10^{\circ} \mathrm{C} \mathrm{min}^{-1}\right)$ to remove water and surface impurities. HCHO saturation of the catalyst surface was performed at room temperature and checked using mass spectrometry (Omnistar, GSD 301-Pfeiffer, Pfeiffer Vacuum, Asslar, Germany). The catalyst was then exposed to He $\left(65 \mathrm{~mL} \mathrm{~min}^{-1}\right)$ for $3 \mathrm{~h}$ to remove physically adsorbed $\mathrm{HCHO}$. The sample was labeled as Mn10HapF.

\subsection{Thermodesorption (TD)-FTIR Study}

The Mn10HapF sample ( $\approx 10 \mathrm{mg}$ ) was pressed into a self-supported pellet and placed in an infrared cell reactor. The thermo-desorption experiment was conducted in He atmosphere $\left(12 \mathrm{~mL} \mathrm{~min}^{-1}\right)$ from $25^{\circ} \mathrm{C}$ to $500{ }^{\circ} \mathrm{C}\left(10^{\circ} \mathrm{C} \mathrm{min}-1\right)$. In line FT-IR measurements were performed using a Nicolet $460 \mathrm{FT}-\mathrm{IR}$ spectrometer equipped with a high sensitivity liquid nitrogen cooled mercury-cadmium-telluride (MCT)/A detector. The FTIR spectra as an average of 32 scans were recorded from 4000 to $1200 \mathrm{~cm}^{-1}$ using a nominal resolution of $4 \mathrm{~cm}^{-1}$. Ambient background was subtracted from all spectra. 


\subsection{Moisture Effect and Regeneration Step}

The Mn10Hap catalyst was activated at $350{ }^{\circ} \mathrm{C}\left(5^{\circ} \mathrm{C} \mathrm{min}^{-1}\right)$ in air flow $\left(100 \mathrm{~mL} \mathrm{~min}{ }^{-1}\right)$ for $2 \mathrm{~h}$ before being cooled down to $135^{\circ} \mathrm{C}\left(1^{\circ} \mathrm{C} \mathrm{min}{ }^{-1}\right)$. After $10 \mathrm{~min}$ of temperature stabilization, the catalyst was submitted to $110 \mathrm{ppmv}$ of $\mathrm{HCHO}$ diluted alternatively in dry and moist air $\left(100 \mathrm{~mL} \mathrm{~min}^{-1}\right.$; VHSV $=500 \mathrm{~mL} \mathrm{~min}{ }^{-1} \mathrm{~g}^{-1}$, several hours at each step for a total duration of $30 \mathrm{~h}$ ). The relative humidity was adjusted by passing dry air through a water bubbler kept in a water bath at $43^{\circ} \mathrm{C}$. After this multi-step experiment, the catalyst was regenerated in flowing air at $350^{\circ} \mathrm{C}$ for $2 \mathrm{~h}$ before cooling down at $135^{\circ} \mathrm{C}\left(0.5^{\circ} \mathrm{C} \mathrm{min}-1\right)$ and was left for $5 \mathrm{~h}$ under air flow at this temperature. Then the catalytic performance of the regenerated catalyst was investigated under $110 \mathrm{ppmv} \mathrm{HCHO} / \mathrm{dry}$ air $\left(\mathrm{VHSV}=500 \mathrm{~mL} \mathrm{~min}{ }^{-1} \mathrm{~g}^{-1}\right.$ ) and on stream for $27 \mathrm{~h}$.

\section{Conclusions}

Mn doped hydroxyapatite catalysts (Mn: 2.5, 5, 10, 20 and $30 \mathrm{wt} \%$ ) synthesized by wet impregnation and calcined at $400^{\circ} \mathrm{C}$ were intensively characterized and tested under $\mathrm{HCHO}$ total oxidation. Structural characterizations showed that the nature of Mn species changed significantly with Mn content: $\beta-\mathrm{MnOOH}$ species were predominantly detected in Mn5Hap and $\mathrm{Mn} 10 \mathrm{Hap}$ samples while $\varepsilon-\mathrm{MnO}_{2}$ phase was present in Mn20Hap and Mn30Hap samples. The catalytic behavior of Hap supported MnOx strongly depended on the Mn content, which is closely related to the nature and local environment of the manganese species. The Mn5Hap catalyst exhibited the best catalytic performance for HCHO oxidation compared with the other catalysts. It was able to convert formaldehyde completely into $\mathrm{CO}_{2}$ at $230{ }^{\circ} \mathrm{C}$ and showed the highest normalized rate of $0.042 \mathrm{~h}^{-1}$ at a temperature of $145^{\circ} \mathrm{C}$. Characterizations indicated that good activity was associated with well dispersed manganese oxides on Hap with a medium Mn AOS. HCHO was retained on the surface of all the catalysts during the catalytic test and formate species were detected such as their oxidation consumed surface $\mathrm{OH}$ groups. A stability test and moisture effect study showed that MnxHap catalysts were active for the complete oxidation of formaldehyde even in the presence of large amount of moisture. However, a slight linear deactivation with time was observed in dry air followed by an enhancement in catalyst activity in humid air. This result indicated that the presence of water vapor has a beneficial effect on the performances of the catalyst. The consumed surface $\mathrm{OH}$ (which acts as an active oxygen species in $\mathrm{HCHO}$ oxidation) was regenerated by water.

Supplementary Materials: The following are available online at http://www.mdpi.com/2073-4344/10/12/1422/s1, Figure S1: Isotherms of the MnxHap samples. Figure S2: XRD patterns of (a) Mn2.5Hap, (b) Mn20Hap and (c) Mn30Hap. Figure S3: (a) In situ Raman spectra as a function of temperature for the precursor of Mn10Hap calcined in $20 \% \mathrm{O}_{2} / \mathrm{He}$ atmosphere; (b) Experimental and fitted Raman spectrum at $100{ }^{\circ} \mathrm{C}$; (c) Comparison of the starting and ending Raman spectrum; and (d) Monitoring of the intensity of the $1050 \mathrm{~cm}^{-1}$ band as a function of temperature. Figure S4: Evolution of $m / z=18, \mathrm{~m} / \mathrm{z}=44$ and $\mathrm{m} / \mathrm{z}=30$ as a function of temperature and Derived weight curve for the decomposition of $(\mathrm{a}, \mathrm{b}) \mathrm{Hap}$ and $(\mathrm{c}, \mathrm{d}) \mathrm{Mn} 10 \mathrm{Hap}$. Figure $\mathrm{S5}: \mathrm{CO}_{2}$ production in the gas phase in the $2000-2800 \mathrm{~cm}^{-1}$ window.

Author Contributions: D.C. prepared the materials and performed the experiments, including the characterization of the catalysts and their catalyst activity tests. Conceptualization, J.-M.G.; Supervision, J.-M.G. and J.-F.L.; Writing-original draft, D.C. and J.-M.G.; Review \& editing, M.L. and J.-F.L. All authors have read and agreed to the published version of the manuscript.

Funding: The European Union through an INTERREG V France-Wallonie-Vlaanderen project "DepollutAir", the Chevreul institute (FR 2638), Ministère de l'Enseignement Supérieur et de la Recherche, Région Nord-Pas de Calais, FEDER as well as the ARCUS E2D2 project and the French Ministry of Foreign Affairs are acknowledged for supporting and funding this work.

Acknowledgments: This work was supported by a grant from the French-Lebanese project PHC CEDRE 2015 No 32933QE and the Lebanese CNRS 2016-2017 project N ${ }^{\circ} 01-08-15$. The authors are grateful to Olivier Gardoll for TGA/MS experiments, Laurence Burylo for XRD measurements, and Elise Bernier for Raman in-situ measurements.

Conflicts of Interest: The authors declare no conflict of interest. 


\section{References}

1. Wang, J.; Li, J.; Jiang, C.; Zhou, P.; Zhang, P.; Yu, J. The effect of manganese vacancy in birnessite-type $\mathrm{MnO}_{2}$ on room-temperature oxidation of formaldehyde in air. Appl. Catal. B Environ. 2017, 204, 147-155. [CrossRef]

2. Zhang, C.; He, H.; Tanaka, K.I. Perfect catalytic oxidation of formaldehyde over a $\mathrm{Pt} / \mathrm{TiO}_{2}$ catalyst at room temperature. Catal. Commun. 2005, 6, 211-214. [CrossRef]

3. Zhang, C.; He, H. A comparative study of $\mathrm{TiO}_{2}$ supported noble metal catalysts for the oxidation of formaldehyde at room temperature. Catal. Today 2007, 126, 345-350. [CrossRef]

4. Li, C.; Shen, Y.; Jia, M.; Sheng, S.; Adebajo, M.O.; Zhu, H. Catalytic combustion of formaldehyde on gold/iron-oxide catalysts. Catal. Commun. 2008, 9, 355-361. [CrossRef]

5. Nie, L.; Yu, J.; Jaroniec, M.; Tao, F.F. Room-temperature catalytic oxidation of formaldehyde on catalysts. Catal. Sci. Technol. 2016, 6, 3649-3669. [CrossRef]

6. Spivey, J.J. Complete catalytic oxidation of volatile organics. Ind. Eng. Chem. Res. 1987, 26, $2165-2180$. [CrossRef]

7. Quiroz Torres, J.; Royer, S.; Bellat, J.P.; Giraudon, J.M.; Lamonier, J.F. Formaldehyde: Catalytic oxidation as a promising soft way of elimination. ChemSusChem 2013, 6, 578-592. [CrossRef]

8. Chang, Y.F.; McCarty, J.G. Novel oxygen storage components for advanced catalysts for emission control in natural gas fueled vehicles. Catal. Today 1996, 30, 163-170. [CrossRef]

9. Sekine, Y. Oxidative decomposition of formaldehyde by metal oxides at room temperature. Atmos. Environ. 2002, 36, 5543-5547. [CrossRef]

10. Quiroz, J.; Giraudon, J.M.; Gervasini, A.; Dujardin, C.; Lancelot, C.; Trentesaux, M.; Lamonier, J.F. Total oxidation of formaldehyde over $\mathrm{MnOx}-\mathrm{CeO}_{2}$ catalysts: The effect of acid treatment. ACS Catal. 2015, 5, 2260-2269. [CrossRef]

11. Ciotonea, C.; Averlant, R.; Rochard, G.; Mamede, A.S.; Giraudon, J.M.; Alamdari, H.; Lamonier, J.-F.; Royer, S. A simple and green procedure to prepare efficient manganese oxide nanopowder for the low temperature removal of formaldehyde. ChemCatChem 2017, 9, 2366-2376. [CrossRef]

12. Chen, T.; Dou, H.; Li, X.; Tang, X.; Li, J.; Hao, J. Tunnel structure effect of manganese oxides in complete oxidation of formaldehyde. Microporous Mesoporous Mater. 2009, 122, 270-274. [CrossRef]

13. Tian, H.; He, J.; Zhang, X.; Zhou, L.; Wang, D. Facile synthesis of porous manganese oxide K-OMS-2 materials and their catalytic activity for formaldehyde oxidation. Microporous Mesoporous Mater. 2011, 138, 118-122. [CrossRef]

14. Zhou, L.; Zhang, J.; He, J.; Hu, Y.; Tian, H. Control over the morphology and structure of manganese oxide by tuning reaction conditions and catalytic performance for formaldehyde oxidation. Mater. Res. Bull. 2011, 46, 1714-1722. [CrossRef]

15. Tian, H.; He, J.; Liu, L.; Wang, D.; Hao, Z.; Ma, C. Highly active manganese oxide catalysts for low-temperature oxidation of formaldehyde. Microporous Mesoporous Mater. 2012, 151, 397-402. [CrossRef]

16. Averlant, R.; Royer, S.; Giraudon, J.M.; Bellat, J.P.; Bezverkhyy, I.; Weber, G.; Lamonier, J.F. Mesoporous silica-confined manganese oxide nanoparticles as highly efficient catalysts for the low-temperature elimination of formaldehyde. ChemCatChem 2014, 6, 152-161. [CrossRef]

17. Xu, J.; White, T.; Li, P.; He, C.; Han, Y.F. Hydroxyapatite foam as a catalyst for formaldehyde combustion at room temperature. J. Am. Chem. Soc. 2010, 132, 13172-13173. [CrossRef]

18. Chlala, D.; Giraudon, J.M.; Nuns, N.; Lancelot, C.; Vannier, R.N.; Labaki, M.; Lamonier, J.F. Active Mn species well dispersed on $\mathrm{Ca}^{2+}$ enriched apatite for total oxidation of toluene. Appl. Catal. B Environ. 2016, 184, 87-95. [CrossRef]

19. Chlala, D.; Griboval-Constant, A.; Nuns, N.; Giraudon, J.M.; Labaki, M.; Lamonier, J.F. Effect of Mn loading onto hydroxyapatite supported Mn catalysts for toluene removal: Contribution of PCA assisted ToF-SIMS. Catal. Today 2018, 307, 41-47. [CrossRef]

20. Wei, W.; Cui, X.; Chen, W.; Ivey, D.G. Phase-Controlled synthesis of $\mathrm{MnO}_{2}$ nanocrystals by anodic electrodeposition: Implications for high-rate capability electrochemical supercapacitors. J. Phys. Chem. C 2008, 112, 15075-15083. [CrossRef]

21. Simon, D.E.; Morton, R.W.; Gislason, J.J. A close look at electrolytic manganese dioxide (EMD) and the $\gamma-\mathrm{MnO}_{2} \& \varepsilon-\mathrm{MnO}_{2}$ phases using Rietveld modeling. Adv. X-ray Anal. 2004, 47, 267-280. 
22. Nakamura, S.; Takeda, H.; Yamashita, K. Proton transport polarization and depolarization of hydroxyapatite ceramics. J. Appl. Phys. 2001, 89, 5386-5392. [CrossRef]

23. Bonel, G. Contribution à l'étude de la carbonatation des apatites. I. Synthèse et étude des propriétés physicochimiques des apatites carbonatées du type A. Ann. Chim. 1972, 7, 65-88.

24. Elliott, J.C. Space group and lattice constants of $\mathrm{Ca}_{10}\left(\mathrm{PO}_{4}\right)_{6} \mathrm{CO}_{3}$. J. Appl. Crystallogr. 1980, 13, 618-621. [CrossRef]

25. Diallo-Garcia, S.; Ben Osman, M.; Krafft, J.-M.; Casale, S.; Thomas, C.; Kubo, J.; Costentin, G. Identification of Surface Basic Sites and Acid-Base Pairs of Hydroxyapatite. J. Phys. Chem. C 2014, 118, 12744-12757. [CrossRef]

26. Cheng, Z.H.; Yasukawa, A.; Kandori, K.; Ishikawa, T. FTIR Study on incorporation of $\mathrm{CO}_{2}$ into calcium hydroxyapatite. J. Chem. Soc. Faraday Trans. 1998, 94, 1501-1505. [CrossRef]

27. Koutsopoulos, S. Synthesis and characterization of hydroxyapatite crystals: A review study on the analytical methods. J. Biomed. Mater. Res. 2002, 62, 600-612. [CrossRef]

28. Julien, C.; Massot, M.; Baddour-Hadjean, R.; Franger, S.; Bach, S.; Pereira-Ramos, J.P. Raman spectra of birnessite manganese dioxides. Solid State Ion. 2003, 159, 345-356. [CrossRef]

29. Ibrahima, M.; Labaki, M.; Giraudon, J.M.; Lamonier, J.F. Hydroxyapatite, a multifunctional material for air, water and soil pollution control: A review. J. Hazard. Mater. 2020, 383, 121139-121156. [CrossRef]

30. Medvecky, L.; Stulajterova, R.; Parilak, L.; Trpcevska, J.; Durisin, J.; Barinov, S.M. Influence of manganese on stability and particle growth of hydroxyapatite in simulated body fluid. Colloids Surf. A Physicochem. Eng. Asp. 2006, 281, 221-229. [CrossRef]

31. Mayer, I.; Cuisinier, F.J.G.; Popov, I.; Schleich, Y.; Gdalya, S.; Burghaus, O.; Reinen, D. Phase relations between $\beta$-Tricalcium phosphate and hydroxyapatite with manganese(II): Structural and spectroscopic properties. Eur. J. Inorg. Chem. 2006, 1460-1465. [CrossRef]

32. Pon-On, W.; Meejoo, S.; Tang, I.M. Substitution of manganese and iron into hydroxyapatite: Core/Shell nanoparticles. Mater. Res. Bull. 2008, 43, 2137-2144. [CrossRef]

33. Lala, S.; Ghosh, M.; Das, P.K.; Karc, T.; Pradhan, S.K. Mechanical preparation of nanocrystalline biocompatible single-phase Mn-doped A-type carbonated hydroxyapatite (A-cHAp): Effect of Mn doping on microstructure. Dalton Trans. 2015, 44, 20087-20097. [CrossRef] [PubMed]

34. Julien, C.M.; Massot, M.; Poinsignon, C. Lattice vibrations of manganese oxides: Part I. Periodic structures. Spectrochim. Acta Part A 2004, 60, 689-700. [CrossRef]

35. Wang, M.; Zhang, P.; Li, J.; Jiang, C. The effects of Mn loading on the structure and ozone decomposition activity of $\mathrm{MnO}_{\mathrm{x}}$ supported on activated carbon. Chin. J. Catal. 2014, 35, 335-341. [CrossRef]

36. Revathi, C.; Kumar, R.T.R. Electro catalytic properties of $\alpha, \beta, \gamma, \varepsilon-\mathrm{MnO}_{2}$ and $\gamma-\mathrm{MnOOH}$ nanoparticles: Role of polymorphs on enzyme free $\mathrm{H}_{2} \mathrm{O}_{2}$ sensing. Electroanalysis 2017, 29, 1481-1489. [CrossRef]

37. Dardenne, K.; Vivien, D.; Ribot, F.; Chottard, G.; Huguenin, D. Mn(V) polyhedron size in $\mathrm{Ba}_{10}\left((\mathrm{P}, \mathrm{Mn}) \mathrm{O}_{4} \mathrm{~F}_{2}\right.$ : Vibrational spectroscopy and EXAFS study. Eur. J. Solid State Inorg. Chem. 1998, 35, 419-431. [CrossRef]

38. Klopproge, J.T.; Wharton, D.; Hickey, L.; Frost, R.L. Infrared and Raman study of interlayer anions $\mathrm{CO}_{3}{ }^{2-}$, $\mathrm{NO}_{3}{ }^{-}, \mathrm{SO}_{4}{ }^{2-}$ and $\mathrm{ClO}_{4}{ }^{-}$in $\mathrm{Mg} / \mathrm{Al}-$ hydrotalcite. Am. Mineral. 2002, 87, 623-629. [CrossRef]

39. Silvester, L.; Lamonier, J.-F.; Vannier, R.-N.; Lamonier, C.; Capron, M.; Mamede, A.-S.; Pourpoint, F.; Gervasini, A.; Dumeignil, F. Structural, textural and acid-base properties of carbonate-containing hydroxyapatites. J. Mater. Chem. A 2014, 2, 11073-11090. [CrossRef]

40. Lamonier, C.; Lamonier, J.-F.; Aellach, B.; Ezzamarty, A.; Leglise, J. Specific tuning of acid/base sites in apatite materials to enhance their methanol thiolation catalytic performances. Catal. Today 2011, 164, 124-130. [CrossRef]

41. Yasukawa, A.; Kandori, K.; Ishikawa, T. TPD-TG-MS study of carbonate calcium hydroxyapatite particles. Calcif. Tissue Int. 2003, 72, 243-250. [CrossRef]

42. Selvakumar, S.; Nuns, N.; Trentesaux, M.; Batra, V.S.; Giraudon, J.-M.; Lamonier, J.-F. Reaction of formaldehyde over birnessite catalyst: A combined XPS and ToF-SIMS study. Appl. Catal. B Environ. 2018, 223, 192-200. [CrossRef]

43. Wang, C.; Zou, X.; Liu, H.; Chen, T.; Suib, S.L.; Chen, D.; Xie, J.; Li, M.; Sun, F. A highly efficient catalyst of palygorskite-supported manganese oxide for formaldehyde oxidation at ambient and low temperature: Performance, mechanism and reaction kinetics. Appl. Surf. Sci. 2019, 486, 420-430. [CrossRef] 
44. Lu, L.; Tian, H.; He, J.; Yang, Q. Graphene- $\mathrm{MnO}_{2}$ hybrid nanostructure as a new catalyst for formaldehyde oxidation. J. Phys. Chem. C 2016, 120, 23660-23668. [CrossRef]

45. Álvarez-Galván, M.C.; Pawelec, B.; De la Peña O’Shea, V.A.; Fierro, J.L.G.; Arias, P.L. Formaldehyde/Methanol combustion on alumina-supported manganese-palladium oxide catalyst. Appl. Catal. B Environ. 2004, 51, 83-91. [CrossRef]

46. Zhou, L.; He, J.; Zhang, J.; He, Z.; Hu, Y.; Zhang, C.; He, H. Facile in-situ synthesis of manganese dioxide nanosheets on cellulose fibers and their application in oxidative decomposition of formaldehyde. J. Phys. Chem. C 2011, 115, 16873-16878. [CrossRef]

47. Liu, P.; Wei, G.; Liang, X.; Chen, D.; He, H.; Chen, T.; Xi, Y.; Chen, H.; Han, D.; Zhu, J. Synergetic effect of $\mathrm{Cu}$ and $\mathrm{Mn}$ oxides supported on palygorskite for the catalytic oxidation of formaldehyde: Dispersion, microstructure, and catalytic performance. Appl. Clay Sci. 2018, 161, 265-273. [CrossRef]

48. Wang, C.; Liu, H.; Chen, T.; Qing, C.; Zou, X.; Xie, J.; Zhang, X. Synthesis of palygorskite-supported $\mathrm{Mn}_{1-\mathrm{x}} \mathrm{Ce}_{\mathrm{x}} \mathrm{O}_{2}$ clusters and their performance in catalytic oxidation of formaldehyde. Appl. Clay Sci. 2018, 159, 50-59. [CrossRef]

49. Han, Z.; Wang, C.; Zou, X.; Chen, T.; Dong, S.; Zhao, Y.; Xie, J.; Liu, H. Diatomite-supported birnessite-type $\mathrm{MnO}_{2}$ catalytic oxidation of formaldehyde: Preparation, performance and mechanism. Appl. Surf. Sci. 2020, 502, 144201-144210. [CrossRef]

50. Wei, G.; Liu, P.; Chen, D.; Chen, T.; Liang, X.; Chen, H. Activity of manganese oxides supported on halloysite towards the thermal catalytic oxidation of formaldehyde: Constraint from the manganese precursor. Appl. Clay Sci. 2019, 182, 105280-105288. [CrossRef]

51. Canepa, P.; Chiatti, F.; Corno, M.; Sakhno, Y.; Martra, G.; Ugliengo, P. Affinity of hydroxyapatite (001) and (010) surfaces to formic and alendronic acids: A quantum-mechanical and infrared study. Phys. Chem. Chem. Phys. 2011, 13, 1099-1111. [CrossRef]

52. Liu, F.; Rong, S.; Zhang, P.; Gao, L. One-Step synthesis of nanocarbon-decorated $\mathrm{MnO}_{2}$ with superior activity for indoor formaldehyde removal at room temperature. Appl. Catal. B Environ. 2018, 235, 158-167. [CrossRef]

53. Ma, C.; Yang, C.; Wang, B.; Chen, C.; Wang, F.; Yao, X.; Song, M. Effects of $\mathrm{H}_{2} \mathrm{O}$ on $\mathrm{HCHO}$ and CO oxidation at room-temperature catalyzed by $\mathrm{MCo}_{2} \mathrm{O}_{4}(\mathrm{M}=\mathrm{Mn}, \mathrm{Ce}$ and $\mathrm{Cu})$ materials. Appl. Catal. B Environ. 2019, 254, 76-85. [CrossRef]

Publisher's Note: MDPI stays neutral with regard to jurisdictional claims in published maps and institutional affiliations.

(C) 2020 by the authors. Licensee MDPI, Basel, Switzerland. This article is an open access article distributed under the terms and conditions of the Creative Commons Attribution (CC BY) license (http://creativecommons.org/licenses/by/4.0/). 